Zabytkoznawstwo i Konserwatorstwo XLIII, Toruń 2012

Maciej Prarat

Instytut Zabytkoznawstwa i Konserwatorstwa UMK

\title{
Rozwój wiejskich miejsc rozrywki na przełomie XIX i XX w. na przykładzie wyników badań historyczno-architektonicznych „Karczmy Rossa” w Górsku, powiat toruński
}

$\mathrm{O}$ d wieków życie człowieka wyznacza czas pracy i odpoczynku. Głównym materialnym śladem związanym właśnie z formą spędzania wolnego czasu na przestrzeni wieków są zachowane budynki karczem. Dziś wiele $z$ nich nie pełni już swojej pierwotnej funkcji, często zatem trudno odgadnąc ich przeznaczenie. Natomiast ich forma i układ przestrzenny może nam wiele powiedzieć o modzie oraz gustach ówczesnych właścicieli i użytkowników. Niegdyś były to miejsca spotkań i biesiad, w przestrzeni, których ludzie tworzyli wspólnotową tożsamość ${ }^{1}$.

Głównym celem niniejszego tekstu jest próba prześledzenia zmian, jakie zaszły w formie i układzie karczmy w drugiej połowie XIX i poczatku XX w. na wsi pomorskiej². Istotnym wydaje się również odpowiedź na pytanie,

1 W odniesieniu do analizy współczesnego doświadczenia biesiadowania patrz: R. Dzięcielski, Miejsca biesiadne - przestrzenie pamięci [w:] Miejsca biesiadne, co o nich opowiada antropolog?, Łódzkie Studia Etnograficzne, t. XLVI, Łódź 2007, s. 9.

2 Główna uwaga skupiona zostanie na ziemi chełmińskiej, na której znajduje się interesująca nas przede wszystkim karczma z Górska. W kilku wybranych przypadkach porównane zostaną do niej przykłady z lewobrzeżnego Pomorza Nadwiślańskiego czy Kujaw. 
na ile czerpały one z modnych wówczas wzorców miejskich. Rozważanie te, dotychczas właściwie nieporuszane, w głównej mierze oparte zostaną na wynikach przeprowadzonych przez autora badań historyczno-architektonicznych „Karczmy Rossa” znajdującej się w podtoruńskiej wsi Górsk (il. 1)³.

Zanim jednak przystapimy do szczegółowych rozważań dotyczacych interesującego nas zabytku, warto przybliżyć ogólny rozwój miejsc rozrywki na tym terenie tak na wsi jak i w miastach. Dopiero tak naszkicowany wstęp, poparty dodatkowo informacjami dotyczącymi zmian, do jakich doszło w dobie uwłaszczenia obszarów wiejskich zaboru pruskiego pozwoli na pełną analizę zagadnienia.

Etymologicznie karczma wywodzi się od wyrazu kerçag oznaczającego dzban ${ }^{4}$. Inaczej określana jest również austeria, gospoda, oberżą, taberną lub zajazdem. W podstawowym znaczeniu jest budynkiem pełniacym funkcje wyszynku, miejsca spotkań i zabaw miejscowej ludności oraz domu zajezdnego przeznaczonego dla podróżnych ${ }^{5}$. Znane były one już w okresie wczesnego średniowiecza ${ }^{6}$.

Miejsca rozrywki odgrywały także istotna rolę w przestrzeni średniowiecznego, lokacyjnego miasta ${ }^{7}$. Wydzielone ku temu budynki o zróżnicowanych typach i formach były bezpośrednim odzwierciedleniem rozwarstwienia społecznego mieszkańców - najbardziej wpływowego patrycjatu, najliczniejszego pospólstwa i nieposiadającego praw miejskich plebsu ${ }^{8}$

3 Badania historyczno-architektoniczne tzw. Karczmy Rossa w Górsku, oprac. M. Prarat, Toruń 2011, w zbiorach Działu Architektury i Parków Etnograficznych Muzeum Etnograficznego w Toruniu [dalej: MET]; Inwentaryzacja pomiarowo-rysunkowa tzw. Karczmy Rossa w Górsku, oprac. M. Prarat, Toruń 2011, w zbiorach Działu Architektury i Parków Etnograficznych MET.

4 Karczma, [hasło w:] A. Brückner, Stownik etymologiczny jezyka polskiego, Warszawa 1970, s. 220.

5 Karczma, [hasło w:] Stownik terminologiczny sqtuk pieknych, Warszawa 2007, s. 177.

6 B. Baranowski, Polska karczma. Restauracja, kawiarnia, Wrocław-Warszawa-Kraków-Gdańsk 1979, s. 7.

7 W Toruniu na przełomie XIV i XV w. było ich ok. 100. Zob. J. Tandecki, Kultura, życie religïne $i$ codzienne XIV-wiecznego miasta, [w:] Historia Torunia, red. M. Biskup, t. 1, Toruń 1999, s. 245; K. Mikulski, Przestrzeń i spoleczeństwo Torunia od końca XIV w. do poczqtku XVII w., Toruń 1999, s. 81. N temat karczm toruńskich patrz również: J. Tandecki, Gospody $i$ szynki dawnego Torunia (do roku 1793 r.), Rocznik Toruński, t. 18, 1988, s. 173-191.

${ }^{8}$ K. Mastykarz, Czas wolny i rozrywka w Toruniu, Chetmnie, Grudziadzu i Brodnicy w XIV-XVI wieku, Toruń 2010, s. 73-77. Zob. również I. Ihnatowicz, A. Mączak, B. Zientara, Spoleczeństwo polskie od X do XX wieku, Warszawa1979, s. 141-148. 
W największych miastach najbardziej reprezentacyjnymi miejscami spotkań dla patrycjatu były Dwory Artusa9. W mniejszych ośrodkach funkcjonowały domy kupieckie ${ }^{10}$. Średnie i niższe grupy społeczne spotykały się w łaźniach miejskich ${ }^{11}$, ogrodach strzeleckich ${ }^{12}$ lub gospodach, które dzieliły się na korporacyjne ${ }^{13}$ oraz dla ogółu społeczeństwa. Dostępność tych ostatnich powodowała, że przesiadywać mogli tam przedstawiciele różnych grup społecznych.

Podział karczm dostosowany był także do samej socjotopografii ośrodka urbanistycznego. Stąd można je było podzielić na miejskie i przedmiejskie. Pierwsze, usytuowane w pierzejach rynkowych, miały formę murowanych kamienic, drugie o znacznie prostszej architekturze budowano w konstrukcji drewnianej na obrzeżach miasta ${ }^{14}$.

Oczywiście zróżnicowanie społeczne odbijało się również w wartościowaniu samej przestrzeni miejsc spotkań i rozrywki. Sytuacje takie możemy odnaleźć tak w patrycjuszowskich Dworach Artusa ${ }^{15}$, jak i przy karczmach zajezdnych, co dla nieco późniejszego okresu opisał w swoim diariuszu z podróży po Polsce Giacomo Fantuzzi: „Tak się postarać trzeba, by oberżysta usadził nas przy głównym stole, z najdogodniejszymi spośród podróżnych, jakich właśnie gości, albowiem nie tylko wiele dowiedzieć się z ich rozmów można [...] lecz także większe poważanie zyskać ${ }^{16}$.

Głównym zajęciem w karczmach, oczywiście poza konsumpcją alkoholu, były również tańce, do których przygrywali muzycy. Nierzadko, oprócz

9 Mowa tu oczywiście o miastach położonych na terenie państwa zakonu krzyżackiego, dalej zaś Prus Królewskich. Zob. E. Pilecka, Średniowieczne Dwory Artusa w Prusach. Świadectwo ksztattowania sie nowej swiadomości mieszrzańskiej, Torun 2005.

${ }_{10}$ Nie miały one jednak charakteru patrycjuszowskiego. Zob. K. Mastykarz, op. cit., s. 131.

11 Ibidem, s. 166, 183.

12 Ibidem, s. 167-168.

13 Do gospod korporacyjnych wstęp miały jedynie osoby należące do danego cechu lub bractwa. Zob. ibidem, s. 153.

14 B. Baranowski, op. cit., s. 11; K. Mastykarz, op. cit., s.159. Karczmy podmiejskie służyły również jako schronienie dla ludzi, którzy nie zdążyli dotrzeć do miasta po zamknięciu bram.

15 E. Pilecka, op. cit., s. 269.

16 Giacomo Fantuzzi. Diariusz podróży po Europie (1652), oprac. W. Tygielski, Warszawa 1990, s. 233 . 
gry w karty czy warcaby uprawiano zakazany hazard (gra w karty lub kości) (il. 2) ${ }^{17}$.

$\mathrm{Na}$ terenach wiejskich w okresie średniowiecza przywilej propinacji posiadały wszystkie warstwy feudalne, a więc panujący, rycerstwo i kościół ${ }^{18}$. Dzięki możliwości przelania uprawnień na inne osoby, zaczęły powstawać karczmy sołtysie oraz tzw. gospody plebańskie, służące m.in. jako miejsce schronienia dla przybywającej na mszę ludności ${ }^{19}$. Tam, gdzie nie było przymusu propinacyjnego, odnaleźć można było także karczmy chłopskie ${ }^{20}$. Często stanowiły one również jedyny we wsi kram, w którym można było także kupić podstawowe produkty ${ }^{21}$.

W okresie nowożytnym sytuacja ta uległa zmianie, co wiązało się bezpośrednio z przejściem od gospodarki czynszowej do folwarcznej. Właściwie zupełnie zanikły karczmy sołeckie i chłopskie ${ }^{22}$, najliczniej zakładane były natomiast przez szlachtę, która czerpała $z$ nich znaczne dochody ${ }^{23}$. Ewoluował także sam zawód karczmarza. Od kmiecia - rolnika mającego w dziedzicznej dzierżawie karczmę i grunt, poprzez urzędnika państwowego na etacie dworskim, kończąc na przemysłowcu i handlarzu, prowadzącego już w XIX w. karczmę na własną rękę ${ }^{24}$.

Elementem rozpoznawczym karczem były zawieszane na elewacjach wiechy $^{25}$ a z czasem również malowane szyldy ${ }^{26}$. Budynki te stawano przy

17 J. Tandecki, Kultura, s. 246.

18 J. Burszta, Wieś i karczma. Rola karczmy w ṡyciu wsi pańszcryyźnianej, Warszawa 1950, s. 25.

19 Zakładane były również przy założeniach klasztornych, do których ściagały liczne pielgrzymki. Zob. Z. Gloger, Budownictwo dreenne i nyroby z dreewa w dawnej Polsce, t. 2, Warszawa 1906, s. 84; T. Chrzanowski, Karczmy i zajazdy polskie, Warszawa 1958, s. 4; J. Burszta, Wieś, s. 25.

${ }^{20}$ W takim samym stopniu dotyczyło to mieszczan. Zob. B. Baranowski, op. cit., s. 10.

21 J. Burszta, Wieś, s. 30-31.

22 W pojedynczych przypadkach dzierżawa karczm przez wójtów, sołtysów czy chłopów w dobrach plebańskich lub królewskich utrzymała się do XVIII w. Zob. M. Szczepaniak, Karcżma, dwór, wies. Rola propinacii na wsi wielkopolskiej od potowy XVII do schytku XVIII wieku, Warszawa 1977, s. 45.

${ }^{23}$ Poza karczmami szlacheckimi w dalszym ciąu utrzymywały się plebańskie. Zob. B. Baranowski, op. cit., s. 12.

${ }^{24}$ Znaczne problemy związane $\mathrm{z}$ obsługa karczm folwarcznych prowadziły do stopniowego sprzedaży tych budynków, które zaczęli nabywać na prawie dziedzicznym zawodowi karczmarze. Zob. J. Burszta, Wieś, s. 143-144; M. Szczepaniak, op. cit., s. 38-39.

25 T. Chrzanowski, op. cit., s. 13.

26 Więcej na ten temat patrz: W. Leonhard, Schöne alte Wirtshausschilder, München 1977. 
głównych traktach, nieraz również w oddaleniu od zabudowań. Przede wszystkim stanowiły jednak jeden z głównych elementów centrum wsi, często wyróżniając się formą od zagród chłopskich.

Dotychczasowa literatura przedmiotu rozróżnia kilka podstawowych typów karczem, charakterystycznych dla większości obszarów Rzeczpospolitej $^{27}$. Typologia ta jest jednak bardzo zróżnicowana, co jest wynikiem różnych kryteriów analizy tego typu założeń. Należy tu zatem zaznaczyć, że zagadnienie to również wymaga nowego spojrzenia, co oczywiście nie mieści się w ramach niniejszego tekstu. Rozpatrując tu głównie układ przestrzenno-funkcjonalny należy w pierwszej kolejności wymienić karczmy bez zajazdu i z zajazdem.

Te pierwsze szarzej analizowane były jedynie dla terenu Wielkopolski ${ }^{28}$. Wśród 7 podstawowych typów (nieróżniących się zasadniczo ani funkcją ani formą od domów chłopskich), najbardziej popularnym był układ z przelotowa sienia na osi środkowej oraz usytuowanymi izbami karczemnymi po jednej stronie i mieszkalnymi, po drugiejej ${ }^{29}$.

Karczmy z tzw. stanem zwane były również zajezdnymi. Sytuowane były przy traktach, często z dala od zabudowy wsi. Różniły się od pierwszych bezpośrednią komunikacja części mieszkalnej ze stajnią i wozownia dla gości ${ }^{30}$. W jego ramach wyróżniono układ blokowy (karczma i stan w jednej linii), w kształcie litery $\mathrm{L}$ oraz $\mathrm{T}^{31}$. Ich cechą charakterystyczna były

27 Do najstarszych prac poświęconych analizie budynków karczm należą teksty B. Podczaszyńskiego i Z. Glogera. Zob. B. Podczaszyński, Budownictwo wiejskie, karczmy, [w:] J. Unger, „Kalendarz Warszawski popularno-naukowy na rok przestępny 1856”, Warszawa 1856; Z. Gloger, op. cit., s. 84-91.

${ }_{28}$ M. Szczepaniak, op. cit., s. 71-74.

29 Ibidem, s. 72.

30 Był to układ najbardziej analizowany przez badaczy. Najstarszy ich podział odnosił się do usytuowania stanu i podcienia. Jeśli sień w osi środkowej ściany wzdłużnej prowadziła bezpośrednio do stanu, to podcień znajdował się wzdłuż tej ściany wejściowej. Jeśli zaś do stanu główne wejście prowadziło osobną drogą z zewnątrz, to podcień posiadał charakter przejazdowy w całej długości ściany wzdłużnej. Zob. Z. Gloger, op. cit., s. 84-91; T. Chrzanowski, op. cit., s. 24-33.

31 W ramach tego podstawowego podziału rozróżniono jeszcze m.in. rzuty w kształcie litery U lub H. Zdarzały się również przykłady, gdzie główny budynek karczmy nie był połączony ze stanem. Zob. M. Szczepaniak, op. cit., s. 73; B. Szurowa, Karczmy na Kielecçyźnie w XVIII i XIX wieku, Kielce 1978, s. 13. 
również podcienia ${ }^{32}$. O wyborze zaś najlepszego miejsca do snu w karczmach zajezdnych znów informuje nas Giacomo Fantuzzi: „Wybrać trzeba pokój od stajni, kuchni i jadalni oddalony, by hałas i ludzkie paplanie snu nie zakłócały, za to w pobliżu części mieszkalnej i ubikacji”33. Co ciekawe, już od początku XIX w. wydawane były instrukcje i zarządzenia dotyczące funkcjonowania i budowy tego typu budynków ${ }^{34}$. Zdarzało się również, że projektowane były one przez uznanych architektów jak np. karczma w Służewie pod Warszawa wg projektu M. Lanciego z 1846 roku $^{35}$.

Przedstawiona charakterystyka zmiany statutu karczmarza jak i układu samych budynków generalnie była taka sama również na terenie Pomorza. W XVIII w., choć rzadko, spotyka się już na ziemi chełmińskiej wolnych karczmarzy. Obok nich funkcjonowali także w dalszym ciagu karczmarze z nadania dworu, wywodząc się z ludności zależnej ${ }^{36}$. W miejscach tych prowadzono również handel, sprzedając główne artykuły spożywcze ${ }^{37}$. Choć rzadko występowały także osobne osady karczmarskie pełniąc również funkcje usługowe ${ }^{38}$.

Nieliczne wzmianki pisane dotyczące tych budynków poświadczaja występowanie wolnostojacych, niewielkich karczm oraz dużych zajazdów, połączonych ze stanem dla podróżnych, znajdujących się przy głównych

${ }^{32}$ Jak wskazuje G. Ruszczyk podcienia były popularne najprawdopodobniej od XVII w. Zob. G. Ruszczyk, Drewno i architektura, Warszawa 2007, s. 68.

33 Giacomo..., s. 232.

34 Mowa tu m.in. o Instrukecji w przedmiocie uporzqdkowania i utraymania w prayszłości porzadku domón zajezdnych i karczem, której kilka wydań wyszło w 1 połowie XIX w. W swojej ksiazzce analizuje je B. Szurowa. Wzorniki architektoniczne popularność zdobyły zaś na początku XIX w. włącznie, np. z wzorami stacji pocztowych, które w końcu doprowadziły do zaniku karczem zajezdnych. Zob. B. Szurowa, op. cit., s. 6; A. Miłobędzki, Zarys dziejón architektury w Polsce, Warszawa 1968, s. 265.

35 Ibidem, s. 283-284 oraz il. 149.

36 S. Cackowski, Struktura spoteczna i gospodarcza wsi wojewódz̨twa chetmińskiego w okresie pierwszego rozbioru Polski. Osadnictwo i ludność chtopska, Toruń 1985, s. 109.

$37 \mathrm{Na}$ temat obowiązków i przywilejów karczmarzy w dobrach kapituły i biskupstwa chełmińskiego patrz. Idem, Gospodarstwo wiejskie w dobrach biskupstwa i kapituly chetminskiej w XVII i XVIII w., cz. 2: Gospodarstwo folwarczne i stosunki rynkowe, Toruń 1963, s. 177-186.

38 Karczmarz w Dzikowie, pow. świecki był jednocześnie przewoźnikiem przez Wisłę pomiędzy Chełmnem a Świeciem. Zob. K. Mikulski, Osadnictwo wiejskie wojewódzৃtwa pomorskiego od potowy XVI w. do końca XVII w., Rocznik TNT, R. 86, Toruń 1994, Z. 2, s. $10,140$. 
traktach (il. 3) ${ }^{39}$. Wspominaja o nich m.in. lustracje z lat 60. XVIII w.: „Karczma [...] w pruski mur, pod dachówka, o 4 izbach, gościniec także w mur pruski pod dachówką ${ }^{40}$. Często same karczmy budowano również w konstrukcji wieńcowej, stany zaś w konstrukcji szkieletowej, deskowanej lub wypełnianej glina ${ }^{41}$. W analizie rozwiązań formalnych pomocnym okazał się również bardzo ciekawy widok wsi Lubicz (il. 4) z 1 połowy XVIII wieku ${ }^{42}$. W opisie osady odnajdujemy karczme oraz górnq karczme z zajazdem ${ }^{43}$. Pierwsza z nich wzdłuż ściany wejściowej ma widocznych sześć słupów konstrukcji szkieletowej ściany (lub podcienia?). Druga, połączona ze stanem zdaje się posiadać klasyczny układ w kształcie litery T.

Jak widać zatem, w XVIII w. występujące tu typy gospod, jak i status samych karczmarzy nie odbiegał w zasadniczy sposób od innych terenów Rzeczpospolitej44.

Największe jednak znaczenie dla rozwoju wsi i miast miały zmiany, do jakich doszło w XIX wieku. Początkowy okres pruskiego panowania łączył się z próbami przeprowadzenia uwłaszczenia, które faktycznie nastapiło jednak dopiero w 2. połowie XIX wieku. Jego wynikiem było przekształcenie nieużytkowanych dotychczasowo ziem oraz wprowadzenie bardziej intensywnych systemów uprawy roli ${ }^{45}$. Do ważnych zmian doszło również w za-

39 S. Cackowski, Gospodarstwo wiejskie, s. 186.

40 Lustracja województw Prus Królewskich 1765, t. 1, Województwo pomorskie, cz. 2: Powiaty tczewski, gdański i nowski, wyd. J. Dygdała, Toruń 2003, s. 147 oraz s. 18, 77.

41 Nie zawsze można jednoznacznie określić, czy stan był bezpośrednio połączony z karczmą. Niezależnie jednak od tego wymieniane są one przy większości karczm. Zob. Lustracja wojewódz̨tw Prus Królewskich 1765, t. 2: Wojewódẓtwo chelmińskie, cz. 2: Ziemia chetmińska, wyd. J. Dygdała, Toruń 2009, s. 4, 10, 22, 23, 34, 38, 54, 77, 85, 97, 100, 103, 120, 124, 127, 137, 146, 159, 192.

42 Toruń i miasta ziemi chetminskiej na rysunkach Jerzego Fryderyka Steinera z. pierwszej połowy XVIII wieku (trw. Album Steinera), Toruń 1998, s. 149.

43 Ibidem, s. 232.

44 Z racji ograniczonych ram pracy nie analizowano już szczegółowo chociażby rozwiazań formalnych, które musiały być zdecydowanie inaczej rozwiązywanych w stosunku np. do terenów południowej Polski.

45 J. Wojtowicz, Stosunki społeçno-gospodarcze Pomorza W schodniego na przełomie XV III $i$ XIX stulecia, [w:] Kryzys ustroju feudalnego i jego instytucii na Pomorzu W schodnim (1772-1815). Prusy Zachodnie $i$ W schodnie w latach 1772-1815, red. J. Wojtowicz, W. Zajewski, H. Rietz, [w:] Historia Pomorza, red. G. Labuda, t. 2, Poznań 1984, cz. 2, s. 655; B. Wachowiak, Reformy 
kresie gospodarki, znosząc w 1810 r. wyłączność produkcji, zaś w 1845 r. prawo wyłączności wyszynku ${ }^{46}$. Miasta, dzięki rewolucji przemysłowej oraz rozwoju kolei znaczenie powiększyły swój obszar. Stanowe podziały feudalne zaczęły się rozmywać, powiększyła się za to grupa robotników.

Karczmarze jako jedni z pierwszych odnaleźli się w realiach gospodarki wolnorynkowej. Nie bez znaczenia były tu również wprowadzane nowe uprawy i rozwój techniki. W XIX w. na większą skalę sadzono już ziemniaki, buraki, rośliny pastewne i oleiste. Dzięki temu m.in. w 2. połowie tego stulecia funkcjonuja już nowoczesne, duże gorzelnie przetwarzające ziemniaki, a nie jak dotychczas zboże ${ }^{47}$. Do rozwoju tej gałęzi produkcji przyczyniło się również otwarcie europejskiego rynku zbytu powołaniem w 1871 r. zjednoczonego Cesarstwa Niemieckiego.

Wszystkie te czynniki spowodowały także istotne zmiany w stylu życia. W większych miastach, wzorując się na dużych ośrodkach europejskich, już w XVIII w. pojawily się kawiarnie i restauracje, zwane również takierniami, przeznaczonymi dla najbogatszej klienteli ${ }^{48}$. Niewiele później coraz bardziej powszednie stały się także hotele ${ }^{49}$. W kręgu wpływów niemieckich na Pomorzu i Ślasku popularność zdobyły piwiarnie przeznaczone dla ogółu mieszczaństwa. Część z nich posiadała również kręgielnie ${ }^{50}$.

W 1. połowie XIX w. występowało kilka rodzajów karczem: nie różniących się zasadniczo od drewnianych domów chłopskich, w których czasem prowadzono również sprzedaż podstawowych produktów spożywczych; o specjalnym ku temu przeznaczeniu często już murowane z cegły, znacznie większe od zwykłych domów, urządzone w specjalne ku temu sprzęty oraz karczmy zajezdne, które poprzez m.in. rozwijającą się kolej, w okresie tym znacznie stracily na znaczeniu ${ }^{51}$. W mniejszych miastach lub

agrarne na Pomorzu w latach 1815-1850, [w:] Historia Pomorza, red. G. Labuda, t. 3, Poznań 1993, cz. 1, s. 191.

46 J. Burszta, Społeczeństwo i karczma. Propinacja, karczma i spawa alkoholizmu w spoteczeństwie polskim XIX wieku, Warszawa 1951, s. 21.

47 Ibidem, s. 37.

48 B. Baranowski, op. cit., s. 36.

49 Ibidem, s. 41.

50 Ibidem, s. 36.

51 Ibidem, s. 71; B. Szurowa, op. cit., s. 8. 
przedmieściach karczmy nadal nie różniły się od tych na wsi. Dodatkowo w mniejszych ośrodkach coraz popularniejsze stawały się restauracje.

Wszystkie te zmiany cywilizacyjne w XIX w. bezpośrednio przełożyły się na formę spędzanie czasu wolnego. W dobie kapitalizmu coraz większe znaczenie w miastach odgrywać zaczął ogół mieszkańców, w tym również prywatnych przedsiębiorców. Zapotrzebowanie na sztukę wysoką - teatr i operę - jedynie dla określonej grupy społecznej, zaczęło ustępować założeniom o znacznie mniejszej skali, gdzie ogół ludności skorzystać mógł z różnych form rozrywki i wypoczynku, tzw. kultury masowej ${ }^{52}$. Dodatkowo potrzeba ta zbiegła się ze znacznym rozwojem przemysłowym ośrodków miejskich, w których zaczęło brakować obszarów zielonych. Wszystkie te potrzeby zaczęły zaspokajać coraz popularniejsze ogrody ludowe, tzw. Etablissements $^{53}$. Mieściły się w nich kręgielnie, hale spacerowe, altany, pergole oraz wydzielona przestrzeń do tańca. Często budowano w nich muszle koncertowe, małe amfiteatry i letnie scenki ${ }^{54}$. Tak zwany Etablissements zakładano w formie nieregularnego parku krajobrazowego, z licznymi budynkami i pawilonami zbudowanymi przeważnie $z$ drewna ${ }^{55}$. Ich forma nawiązywała częściowo do XVIII-wiecznych pawilonów klasycystycznych czy architektury zdrojowej ${ }^{56}$. Warto jednakże pamiętać, że ogrody należały do popularnych miejsc spędzania wolnego czasu już od średniowiecza ${ }^{57}$.

$\mathrm{Na}$ terenie Niemiec najważniejsze założenia tego typu powstały w XIX wieku. Były to Tivoli w Hamburgu z 1839 r., berliński Kroll's Wintergarten z 1843 r. oraz Flora z 1865 r. (również w Koloni) ${ }^{58}$. Na terenie dzisiejszej

52 Z. Ostrowska-Kębłowska, Architektura $i$ budownictwo w Pornaniu w latach 1790-1880, Warszawa-Poznań 1982, s. 432.

53 Pierwszym ogrodem rozrywki przeznaczonym dla szerszego grona odbiorców był założony w 1661 r. podlondyński Vauxhall, dalej zaś wiedeński Prater z 1766 r. czy Jardin de Tivoli w Paryżu z 1795 r. Zob. M. Jagiełło-Kołaczyk, Wrocławskie ,établissements” typu ogrodu ludowego, [w:] Architektura Wrockawia, t. 4: Gmach, red. J. Rozpędowski, Wrocław 1998, s. 536-437; J. Weisser, Zwischen Lustgarten und Lunapark, Die Volksgarten Nymphenburg (1890_ -1916) und die Entwicklung der Kommerziellen Belustgungsgärten, München 1998, passim.

54 Z. Ostrowska-Kębłowska, Architektura, s. 434.

55 Ibidem, s. 434.

56 Ibidem.

57 L. Majdecki, Historia ogrodów, t. 1, Warszawa 2007, s. 82-84.

58 M. Jagiełło-Kołaczyk, op. cit., s. 138. 
Polski powstawały m.in. w Poznaniu ${ }^{59}$ czy Wrocław, w granicach którego od końca XVIII w. do lat 80. XIX w. powstało sześć tego typu zespołów ${ }^{60}$.

$\mathrm{Na}$ interesującym nas obszarze Pomorza ogrodowe założenia teatralnorozrywkowe również powstały w większych miastach. W Bydgoszczy można było spotkać dwa typy ogrodów, różniących się wielkością i programem funkcjonalnym. Większe mieściły w ogrodzie scenę letnią, budynek z salą bankietowo-teatralna, bufet, altanę dla orkiestry, werandy do tańca, oranżerię oraz pomieszczenia gospodarcze i kuchenne. Mniejsze składały się z sali restauracyjnej z estradą oraz dodatkowych pomieszczeń, w tym kręgielni i strzelnic ${ }^{61}$. Pierwsze założenia tego typu pojawiły się około połowy XIX wieku ${ }^{62}$. Do najważniejszych założeń należały Etablissement Patzera z 1860 r. czy Dom Bractwa Strzeleckiego Schützenhaus z 1866 r., którego projekt wykonał berliński architekt Eduard Titz, twórca m.in. berlińskiego Kroll's Etablissement ${ }^{63}$.

$\mathrm{Na}$ terenie Torunia na bydgoskim przedmieściu najstarszym i najpopularniejszym tego typu założeniem był funkcjonujący już w 1834 r. Park Cegielnia ${ }^{64}$. Także na chełmińskim przedmieściu mieścił się kompleks restauracyjno-rozrywkowy Park $W$ iktorii $^{65}$.

Warto również odnotować, iż tego rodzaju założenia spotkać można było i w mniejszych miejscowościach, ich układ zaś czasem był bardziej rozbudowany niż w samej Bydgoszczy ${ }^{66}$. Do przykładów takich należał Etablissement Grabina-Wäldchen w Koronowie, założony w 1873 roku $^{67}$.

59 Z. Ostrowska-Kębłowska, Architektura, s. 436-438.

${ }^{60}$ Były to Prinz v. Preussen, Wintergarten, Volksgarten, Friebeberg, Schiesswerder oraz Bürgersäle. Zob. M. Jagiełło-Kołaczyk, op. cit., s. 139-164.

${ }^{61}$ D. Brzęczewska-Kulesza, B. Derkowska-Kostkowska, Etablissement - ogrodowe zatożenia teatralno-rozrywkowe, [w:] Praybytki Melpomeny. Katalog mystany 16 kwietnia - 8 czerwca 2008, Bydgoszcz 2008, s. 27. Na ten temat zobacz również: B. Derkowska-Kostkowska, Dawne kompleksy restauracyjno-rozrywkowo-teatralne w Bydgoszçy, [w:] Siedziby teatrón, teatraykón, oper, filharmonii - historia $i$ architektura, red. D. Brzęczewska-Kulesza, A. Wysocka, Bydgoszcz 2008, s. 93-102.

62 D. Brzęczewska-Kulesza, B. Derkowska-Kostkowska, op. cit., s. 28.

${ }^{63}$ Ibidem, s. 30.

${ }^{64}$ J. Kucharzewska, Architektura i urbanistyka Torunia w latach 1871-1920, Warszawa 2004, s. 172. Na ten temat zobacz również: Od Parku Cegielnia do klubu Azyl, czyli jak sie bawit Toruń. Katalog mystany 22 stycznia - 25 marca 2011, Toruń 2011, s. 20-21.

65 J. Kucharzewska, op. cit., s. 173.

${ }^{6}$ E. Okoń, Koronowo - rozwój przestrzenny i przeobrażenia na przestrženi dziejów, [w:] Džieje Koronowa, red. D. Karczewski, Koronowo 2009. s. 283-284.

${ }^{67}$ Ibidem, s. 283. 
Tak naszkicowane tło rozwoju miejsc, w których spędzano czas wolny, zwłaszcza w XIX w., pozwala nam na bliższe przyjrzenie się karczmie Rossa w Górsku. Tekst ten jest oparty na dokumentacji opracowanej przez autora w maju 2011 roku $^{68}$.

Badania historyczne objęły kwerendę archiwalną w Wojewódzkim Urzędzie Ochrony Zabytków w Toruniu' ${ }^{69}$ oraz Państwowym Archiwum w Toruniu ${ }^{70}$. Badania architektoniczne objęły analizę układów konstrukcyjnych, złącz ciesielskich, zastosowanego budulca oraz jego obróbki. Suma tych informacji dała możliwość rozwarstwienia chronologicznego a w dalszej kolejności wykonania teoretycznej rekonstrukcji stanu pierwotnego oraz wybranych późniejszych przekształceń.

Źródła piśmienne wymieniaja po raz pierwszy kępę Gorzk w przywileju lokacyjnym Torunia ${ }^{71}$. Samą zaś wieś Górsk w krzyżackim dokumencie lokacyjnym z 1346 roku $^{72}$. Już w tym okresie wymienia się w osadzie karczmę, sama zaś miejscowość stanowiła ważną bazę zaopatrzeniową dla zamku toruńskiego.

W 1454 r. Górsk znalazł się w granicach Rzeczpospolitej, wchodząc w skład województwa chełmińskiego, zaś od 26 sierpnia 1457 r. w skład dóbr miasta Torunia. Ważnym wydarzeniem w historii miejscowości było osiedlenie się na prawie długoterminowej dzierżawy menonitów ${ }^{73}$. Z koń-

68 Dokumentacja miała charakter ratunkowy. Wykonana została dzięki informacji społecznego opiekuna zabytków A. Walczyńskiego o decyzji rozbiórki zabytku przez gminę Zławieś Wielka, której dokonano we wrześniu 2011 r.

${ }^{69}$ Górks, karczma. Karta Ewidencji Zabytków Architektury i Budownictwa, tzw. zielona karta, Toruń 1959, mps w zbiorach Wojewódzkiego Urzędu Ochrony Zabytków w Toruniu.

${ }^{70}$ Archiwum Państwowe w Toruniu [dale:j APT], Akta Urzędu Katastralnego w Toruniu sygn. 175 Beschreibung der auf der nachbezeichneten Besitzung neuerbauten oder veränderten Gebäude, Gemeinde Bezirk Gurske (Gursk), nr 7.

71 Katalog zabytków Sz̨tuki w Polsce, t. XI, Województwo bydgoskie, red. T. Chrzanowski, M. Kornecki, Z. 16, powiat torunski, oprac. T. Chrzanowski, M. Kornecki, Warszawa 1972, s. 32.

72 H. Maercker, Geschichte der Ländlichen Ortschaften und der drei Kleinerem Städte des Kreises Thorn, Danzig 1899-1900, s. 273.

73 K. Bartowski podaja datę sprowadzenia nowych osadników na 1567 r. Nie odpowiada to informacjom o ponownej lokacji wsi na prawie magdeburskim w 1576 r. i dopiero w 1594 r. na prawie olęderskim. Por. H. Maercker, Geschichte, s. 247; R. Heuer, 
ca XV w. znany jest karczmarz, Michał z Górska użytkujący najprawdopodobniej karczmę „Żalsięboże"74.

W okresie zaborów wieś znalazła się pod panowaniem pruskim, przynależąc do rejencji kwidzyńskiej. Pod koniec XVIII w. wymienione były we wsi dwie karczmy, znana już wcześniej „Żalsięboże” oraz „Zazdrość,, leżąca przy granicy ze Smolnem ${ }^{75}$. Na początku XIX w. wieś dzieliła się na dwa niezależne dobra należące do miasta Torunia. W pierwszym z nich wymieniono obok kościoła luterańskiego, plebani, szkoły i kuźni również karczmę ${ }^{76}$, natomiast czy informacja ta dotyczy interesującego nas budynku czy któregoś ze wcześniej wymienionych, nie wiadomo.

Najstarsze znane informacje dotyczace interesującej nas bezpośrednio karczmy pojawiają się w źródłach dopiero w ostatniej ćwierci XIX wieku${ }^{77}$.W okresie tym jej właścicielami byli rolnicy Fryderyk i Karol Ross. Użytkowana była również podczas okupacji ${ }^{78}$. W okresie powojennym budynek przejęty został przez państwo. Znajdowały się w nim mieszkania socjalne, co bezpośrednio przyczyniło się do pogorszenia stanu zachowania.

Karczma usytuowana jest na wschód od kościoła, ścianą wzdłużną do drogi biegnacej równolegle do wału przeciwpowodziowego ${ }^{79}$. $\mathrm{Na}$ działce poza budynkiem karczmy, ścianą szczytową do drogi usytuowany jest murowany garaż. Ścianą zachodnią łączy się z murowanym budynkiem mieszkalnym.

Die Holländerdörfer in der Weichselniederung um Thorn, „Mittteilungen des Coppernicus-Vereins für Wissenschaft und Kunst zu Thorn”, Z. 42, Toruń 1934, s. 123; K. Ciesielska, Osadnictwo ,olederskie” w Prusach Królewskich i na Kujawach w swietle kontraktów osadnicsych, „Studia i Materiały z dziejów Wielkopolski i Pomorza”, t. 4, 1958, s. 224; W. Maas, Zur Siedlungskunde Westpreussens 1466-1772, Marburg/Lahn 1958, s. 47; A. Goertz, Mennoniten in den Thorner Niederungen, „Westpreußen Jahrbuch”, Jg. 13, 1963, s. 123; K. Bartowski, Historia osadnictwa olederskiego na terenie gminy Solec Kujawski, [w:] Zabytki osadnictwa olederskiego w gminie Solec Kujawski - materialy z sesji, Bydgoszcz 1993, s. 7; A. Walczyński, Górsk i okolice od prebistorii do polowy XX wieku, Toruń 2005, s. 30.

74 Ibidem, s. 34.

75 Ibidem, s. 30.

76 H. Maercker, op. cit., s. 278.

77 Archiwum Państwowe w Toruniu (dalej: APT), Akta Urzędu Katastralnego w Toruniu (dalej: UKT), sygn. 175 Beschreibung der auf der nachbezeichneten Besitzung neuerbauten oder veränderten Gebäude, Gemeinde Bezirk Gurske (Gursk), nr 7.

78 A. Walczyński, op. cit., s. 62.

79 Dla bardziej przejrzystej narracji opis sporządzono w czasie teraźniejszym do stanu z maja 2011 r., kiedy budynek jeszcze istniał. 
Budynek zbudowany jest na rzucie prostokata o wymiarach $10 \times 16 \mathrm{~m}$ w układzie dwutraktowym. Wejścia znajdują się w ścianie południowej i wschodniej. Główne w ścianie południowej prowadzi do sieni skomunikowanej $\mathrm{w}$ jednym trakcie z izba po stronie zachodniej i wschodniej. Obie izby skomunikowane sa z kolejnymi w trakcie północnym. Dodatkowo z izby zachodniej prowadzi przechód do sieni od szczytu. W sieni południowej znajduja się również schody na poddasze. Od strony pólnocnej sień łączy się z usytuowaną centralnie czarną kuchnią, skomunikowaną dodatkowo $\mathrm{w}$ trakcie południowym $\mathrm{z}$ pomieszczeniem kuchni oraz izbami po bokach. Pierwsza po stronie wschodniej łączy się dodatkowo z kolejną od ściany szczytowej. W sieni szczytowej znajduje się zejście do piwnicy. Poddasze o użytkowym charakterze ma od wschodniej ściany szczytowej wydzieloną izbę mieszkalną. Centralną część poddasza zajmuje komin butelkowy. W partii przyziemia posiada on jedno palenisko z kapturem, usytuowane w narożniku południowo-wschodnim. Pomieszczenie to przekrywa strop z dykty. W poddaszu brak wydzielonego pomieszczenia wędzarni.

Budynek o formie prostopadłościanu nakryty jest dachem dwuspadowym. Elewacja północna jest pięcioosiowa niesymetryczna zaś elewacja południowa czteroosiowa, niesymetryczna. Po stronie zachodniej usytuowany jest ganek wejściowy, nakryty daszkiem dwuspadowym. Elewacja wschodnia w partii przyziemia jest trójosiowa niesymetryczna. W większości widoczne są na nich bierwiona konstrukcji wieńcowej, częściowo zaś są one otynkowane.

Budynek wzniesiony został w konstrukcji wieńcowej na podmurówce z kamienia polnego na zaprawie wapiennej, z rolką cegły wyrównującej od góry. Drewniane podłogi znajdują się w sieni i izbach, w kuchni i czarnej kuchni sa zaś cementowe. Więźba dachowa ma konstrukcję jednojętkową z ramą stolcowa, wzmocniona dodatkowo mieczami. Fragmenty ścianek działowych, ściany północnej oraz komin butelkowy wymurowano z cegły. Dach pokryty jest dachówką esówką.

Stolarka okienna ma konstrukcję ościeżnicową ze słupkiem okiennym, gdzie szyby szklone są na kit, zaś stolarka drzwiowa jest ramowo-płycinowa o dwóch lub czterech polach. Pierwotne wyposażenie budynku nie zachowało się. 
Karczma od strony zachodniej połączona jest z murowaną dobudówką na rzucie prostokąta, którą nakrywa dwuspadowy dach o znacznie niższej kalenicy. Z racji braku dostępu, nie będzie ona szerzej charakteryzowany, zaś wszelkie informacje na jej temat pochodzić będa ze źródeł pisanych i ikonograficznych ${ }^{80}$.

W tym momencie możemy już przejść do prezentacji wyników badań architektonicznych. Należy ją zacząć omówieniem wyników analizy, potem zaś chronologicznego rozwarstwienia historii budowlanej, kończąc zaś próbą rekonstrukcji pierwotnego układu oraz wybranych późniejszych faz przekształceń.

Analiza podzielona została na dwie najistotniejsze konstrukcyjnie części karczmy, tj. wieńcowy korpus z murowanym kominem oraz więźbę dachową (il. 5). Omówione zostaną one osobno, w kolejności zastosowanych złącz ciesielskich, dalej zaś obróbki i wielkość elementów oraz systemu ciesielskich znaków montażowych.

Korpus karczmy wykonany został w konstrukcji wieńcowej. Każda ze ścian składa się z ośmiu bierwion ułożonych kolejno na sobie. Cała konstrukcja posadowiona jest na podmurówce ceglanej. Podwaliny ze względu na zły stan zachowania nie mogły być przebadane. Bierwiona łączą się w narożnikach wschodnich na jaskółczy ogon z ostatkami i środkowym posiłkiem ${ }^{81}$. Pomiędzy sobą łączą się tyblami, w nieregularnych odstępach.

Wszystkie stolarki okienne łączą się ze ścianami na styk. Ościeżyny drzwi w ścianie wschodniej łączą się z bierwionami na czop, zaś w ścianie północnej i południowej na styk. Nie udało się przebadać połączeń ościeżyny ze ściana zachodnią. Ganek w części południowej jest niezależną konstrukcją szkieletową w stosunku do korpusu.

Ściany nośne z działowymi w trakcie południowym łączą się na czop płetwowy ${ }^{82}$. W trakcie północnym nie udało się ich przebadać. Ściana międzytraktowa w części zachodniej została wymurowana z cegły. W części

${ }^{80}$ Dokładny opis został celowo pominięty przez autora. Znaczne przekształcenia budynku, jego obecna niedostępność oraz zawarty rysunek stanu pierwotnego w źródłach pisanych niepublikowanych wystarczają do analizy rozwoju całego założenia.

81 Z powodu niedostępności narożników zachodnich nie udało się ich przebadać.

82 Pomiędzy sienią i izbą obok tego połączenia zachowane jest gniazdo o analogicznej formie. Najprawdopodobniej jednak nigdy nie zostało wykorzystane, o czym świadczy ana- 
wschodniej od komina wykonano ja już w konstrukcji murowanej, za otworem drzwiowym zaś drewnianej, łącząc się ze ścianą szczytową na styk.

Widoczny w elewacji wschodniej podciag, pomiędzy którym fazowana jest belka wiązarowa nie ma przedłużenia w środku. Został on obcięty. W sieni szczytowej zachowany jest ślad w podwalinie, w postaci fleka ${ }^{83}$ (il.6). Flek ciągnie się wzdłuż całej ściany szczytowej. Na jego osi w kolejnych belkach wiązarowych zachowane sa kolejne ślady zaflekowanych gniazd. W tym miejscu usytuowana być musiała pierwotna ścianka działowa.

Schody na poddasze w sieni południowej zamocowane zostały w wieńcowej poprzecznej ściance drewnianej, która połączona jest ze słupem dochodzącym do ścianki murowanej na czop.

Czarna kuchnia wykonana została w konstrukcji murowanej z cegły palonej. W ścianie wschodniej zachowała się prostokątna nisza, od której odchodzi pod kątem w górę rolka cegły świadcząca o pierwotnym łuku. Wypełnienie ceglane samej niszy również jest wtórne. W części północnej dostawiony jest kanał dymny, połączony z główną ścianą na styk. W ścianie wschodniej znajduje się analogiczna nisza o pierwotnym zamknięciu łukiem odcinkowym, również wtórnie zamurowana. W narożniku południowo-wschodnim dostawiono duży kanał dymny, zaś w połowie wysokości niszy dostawiono kaptur, pod którym usytuowany musiał być piec kuchenny. Wszystkie te elementy murowane są na styk do głównej ściany komina. Sama kuchnia przesklepiona jest prowizorycznie dykta.

Do wykonania konstrukcji wieńcowej użyto półdrzewa o średnim wymiarze 25/16 cm. Od strony zewnętrznej pozostawiono oflis, świadczący o obróbce siekierą i toporem. W obrębie korpusu nie odnaleziono ciesielskich znaków montażowych.

Wyniki analizy upoważniają do stwierdzenia, iż wszystkie ściany nośne, okna w ścianie południowej oraz odrzwia w ścianie wschodniej sa pierwotne ${ }^{84}$.

logiczne połączenie ścianki obok, jak i sam układ przestrzenno-funkcjonalny, w ramach, którego ścianka w tym miejscu nie mogłaby istnieć.

83 Podwalina po bokach jest również fazowana.

84 Zachowane jedynie dwa okna w ścianie południowej mają odmienną formę ze słupkiem. Są nieco niższe. Inne stolarki, choć o tej samej konstrukcji, ale już z krzyżem okiennym posiadaja już większe rozmiary, zaś o ich wtórnym charakterze świadczy podcięcie oczepu, w który weszły nadokienniki. 
Z okresu budowy zachowane są ścianki działowe pomiędzy sieniami i izba w trakcie południowym ${ }^{85}$ oraz ścianki pomiędzy izbami i kuchnią w trakcie północnym. Do elementów wtórnych zaliczono fragment murowany ściany północnej, ganek, wszystkie stolarki okienne oraz drzwi w ścianie północnej i wschodniej; obie ścianki międzytrakowe oraz ściankę dzieląca pokoje w trakcie północnym; nisze w czarnej kuchni wraz z kapturem i wszystkimi kanałami dymnymi.

Więźba dachowa ma konstrukcję jętkowa, dwustolcowa, złożona z jedenastu wiązarów. Zastosowano w niej redukcję poprzeczna, w co drugim wiązarze, w którym brak stolców. Rama wzdłużna składa się ze stolców wchodzących w płatew i dodatkowo wzmocnionych mieczami. Belka wiązarowa łączy się z oczepem na wrąb jednostronny. Krokiew wchodzi w belkę na czop środkowy skośny. Jętka łączy się z krokwiami na czop pełen, kołkowany. Krokwie w kalenicy połączone są na widełki kryte. Stolec wchodzi w belkę wiązarową na czop środkowy, z płatwią łączy się na czop pełen kołkowany. Płatew zaś z jętką połączona jest na wrąb jednostronny. Miecze z płatwia jak i stolcem łączą się na czop pełen kołkowany.

Do wykonania wszystkich elementów więźby zastosowano całe drzewo o średnim wymiarze $18 / 16 \mathrm{~cm}$. Budulec obrobiony został siekiera i toporem.

W konstrukcji zastosowano dwa systemy ciesielskich znaków montażowych. Poprzeczny dla każdego wiązara oraz podłużny dla wzdłużnej ramy stolcowej. Pierwszy z nich narasta zgodnie z numeracją wiązarów, licząc od pierwszego szczytowego. Zastosowano w nim formę cyfr rzymskich, które wykonano dwoma cięciami siekierą. Znaki w poszczególnych wiązarach odnaleziono na każdej krokwi oraz jętce. Nie udało się odnaleźć znaków na wszystkich wiązarach, zwłaszcza od strony wschodniej, z powodu obudowania części elementów ścianami izby mieszkalnej. Również w obu wiazarach szczytowych nie odnaleziono znaków montażowych, co wynika z odwiązania ich od strony zewnętrznej, obecnie oszalowanej.

${ }^{85} \mathrm{~W}$ przypadku ścianki oddzielającej sień wschodnią od izby należy zaznaczyć, iż ścianka ta zachowana jest do otworu drzwiowego. Choć osadzenie drzwi na czop jest analogiczne do oryginalnych drzwi wejściowych, należy uznać je jako wtórne z racji przebiegającej na tej linii pierwotnej ścianki międzytraktowej z podciagiem. 
Nieco inaczej wygląda system wzdłużny. Znaki, również o formie cyfr rzymskich, umieszczono na wszystkich mieczach, płatwiach i stolcach ${ }^{86}$, z tym, że od góry (płatew i górna część miecza) wykonane zostały sangwiną zaś dolna (stolec i dolna część miecza) dłutem. Druga strona wykonana została analogicznie, z zastosowaniem przyznaku w formie ukośnej kreski.

Analiza układu konstrukcyjnego, złącz ciesielskich, sposobu obróbki, systemu ciesielskich znaków montażowych nie wykazuja zmian w obrębie więźby. Jedynym elementem wtórnie wprowadzonym jest najprawdopodobniej izba w szczycie.

Przeprowadzona analiza całości pozwoliła na chronologiczne rozwarstwienie substancji zabytkowej. Została ona ustalona częściowo na podstawie informacji zaczerpniętych $z$ akt archiwalnych, częściowo na ogólnej wiedzy z zakresu rozwoju konstrukcji i form budownictwa drewnianego.

Z pierwszym etapem budowy karczmy na początku XIX w. można powiązać wszystkie ściany wieńcowe korpusu oraz częściowo ścianki działowe, obwód przyziemia czarnej kuchni wraz z kominem butelkowym a także całą więźbę dachowa ${ }^{87}$. Z detalu zachowały się jedynie dwa okna ościeżnicowe ze słupkiem w ścianie południowej, odrzwia w elewacji wschodniej oraz drzwi wewnętrzne pomiędzy sienią i izbą traktu południowego.

Z drugim etapem, który nastapić musiał w XIX w., należy łączyć zmiany w układzie przestrzenno-funkcjonalnym części wschodniej ${ }^{88}$. Wtedy to wykonano nową ściankę międzytraktowa. Wymusiło to obcięcie podciągu, na osi, którego w ściance działowej wprowadzono wtórne drzwi. Wymieniono stolarki okienne w ścianie szczytowej i północnej. Na poddaszu wykonano dodatkową izbę mieszkalna, zmieniając jednocześnie odeskowanie szczytu ${ }^{89}$.

\footnotetext{
${ }^{86}$ Nie udało się zidentyfikować znaków w pierwszych wiązarach $z$ racji obudowania tej części izbą mieszkalna.

87 Datowanie to oparto na analizie konstrukcji budynku. Ręczna obróbka wszystkich elementów, czy poszczególnych złącz ciesielskich świadczyć może o starszej proweniencji. Komin murowany z cegły palonej, z pierwotnie umieszczonymi trzonami kuchennymi od izby, świadczyć musi jednak o budowie budynku najdalej na przełomie XVIII i XIX w.

${ }_{88}$ Rysunki sporządzone do dokumentacji urzędu katastralnego pokazują budynek już po wprowadzonych zmianach. Zob. APT, UKT, sygn. 175, załącznik nr 1 do wykazu zmian.

89 Wymiana stolarek okiennych w tym okresie została określona na podstawie analogii formalnej do okna w szczycie. Izba ta istnieć musiała natomiast przed końcem XIX w.,
} 
W trzecim etapie w latach 1897-1898 pojawił się ganek w ścianie południowej, zamurowano wejście do kuchni wprowadzając nowe okno. Wymieniono ściankę międzytraktową części zachodniej. W okresie tym musiały przestać funkcjonować trzony kuchenne, które zamurowano, wprowadzając kanały dymne dla pieca kuchennego i pieców grzewczych ulokowanych w izbach ${ }^{90}$. Największą zmianą była jednak dobudowa nowego budynku po stronie zachodniej"

Okres powojenny łączył się głównie ze zmianą użytkowania budynku. Został on podzielony na niezależne mieszkania. Od strony zewnętrznej konstrukcja wieńcowa została częściowo otynkowana a ganek zabudowany. Wykonano ścianę z dykty pomiędzy izbami traktu północnego ${ }^{92}$.

Do elementów wtórnych nie datowanych należą natomiast drzwi i małe okno w ścianie szczytowej, wschodniej, zaś do elementów nieokreślonych zakwalifikowano schody na poddasze.

Suma tych wszystkich informacji dała podstawę do opracowania rekonstrukcji stanu pierwotnego (il. 7$)^{93}$. W okresie powstania dwutraktowy układ przestrzenny w pełni podporządkowany był funkcji karczemnej. Wejścia znajdowały się w obu ścianach wzdłużnych, prowadząc do dwóch sieni na jednej osi. Pomiędzy nimi znajdowała się czarna kuchnia. W trakcie północnym po obu stronach sieni znajdowały się dwie izby - wschodnia karczemna oraz zachodnia - mieszkalna. W nich to usytuowane były trzony kuchenne, w których gotowano ${ }^{94}$. Czarna kuchnia nie była przeskle-

o czym informuje nas opis archiwalny. Zob. APT, UKT, sygn. 175, nr 7 - opis domu mieszkalnego.

90 Zamurowanie trzonów łączyć się musiało z wprowadzeniem kanałów dla ogrzewania izb piecami. Opis z 1926 r. wymienia już izby gościnne i mieszkalne z piecami grzewczymi. Przed przebudową akta wymieniają 2 ogrzewane izby mieszkalne i 2 ogrzewane izby gościnne, które grzane musiały być najprawdopodobniej samym kominem butelkowym i paleniskiem w czarnej kuchni. Zob. APT, UKT, sygn. 175, nr 7 oraz załącznik nr 1 do wykazu zmian.

91 Analiza ta przeprowadzona została jedynie na podstawie akt archiwalnych. Por. przyp. 77.

92 Współczesna ściana musiała jednak nawiązywać do układu z początku XX w., kiedy pomieszczenia te również były przedzielone.

93 Poszczególne elementy podzielono w niej na pierwotne, rekonstruowane na podstawie badań oraz rekonstruowane hipotetycznie.

${ }_{94}$ Trzony te zrekonstruowane zostały hipotetycznie. Musiały istnieć w podobnej formie to tych z II fazy przebudowy, lecz musiały być cofnięte bardziej w stronę północną, co wynikało z pierwotnego usytuowania ścianki międzytraktowej w części wschodniej. 
piona, zaś dym z trzonów uchodził bezpośrednio przez komin butelkowy. Izba karczemna skomunikowana była dodatkowo z kolejna izbą dla gości i komora w trakcie południowym ${ }^{95}$. Izba mieszkalna łączyła się z kolejna w trakcie południowym. Obie sienie skomunikowane były z izbami po obu stronach w jednym jak i drugim trakcie. Dodatkowo komora posiadała wejście w ścianie szczytowej. W ścianie południowej znajdowały się jedynie dwa otwory okienne doświetlające obie izby mieszkalne ${ }^{96}$. Pod komora znajdowała się mała piwniczka. Okna zostały zrekonstruowane na podstawie zachowanych dwóch w ścianie południowej. Budynek w całości zbudowany był w konstrukcji wieńcowej, zawęgłowanej na jaskółczy ogon z ostatkami. Wejście od strony drogi wyłożone było brukiem. W obrębie obejścia znajdować się mógł również jakiś budynek inwentarski lub wozownia dla gości.

Jak już stwierdzono w rozwarstwieniu, przekształcenia z 2. połowy XIX w. polegały głównie na zmianach w układzie przestrzenno-funkcjonalnym. Zwiększono powierzchnię izby i komory w trakcie południowym, tworzac z nich sień wejściową i główną izbę karczemną. Duża izba po stronie północnej została podzielona na dwa mniejsze pomieszczenia - spiżarki i kolejnej izby karczemnej. Zmiana w usytuowaniu pierwotnej ścianki działowej wymusiła również znaczne zmiany w przestrzeni czarnej kuchni, gdzie przesunięciu ulec musiały w kierunku wschodnim całe trzony kuchenne $^{97}$. Zamknięte łukiem odcinkowym usytuowane zostały na jednej osi.

W okresie tym do karczmy dostawiony był już szkieletowy budynek kryty papa, w którym usytuowano ogrzewaną salę do tańca ${ }^{98}$. W obrębie podwórza funkcjonował szkieletowy budynek inwentarski mieszczący 8 koni dla gości, oraz 1 konia, 2 krowy i świnie karczmarza. Budynek ten był usytuo-

95 Nie mogło być przechodu pomiędzy komorą a izbą w tym samym trakcie, o czym świadczy zachowana oryginalna ścianka działowa między nimi.

96 Cała ściana zachodnia została zrekonstruowana hipotetycznie. Dobra komunikacja izb z sienia zdaję się nie wymuszała wprowadzania kolejnych drzwi.

${ }^{97}$ Analogicznie zaznaczono w dokumentacji zmiany w obrębie drugiej ścianki z trzonem, choć poprzez liczne przemurowania bezpośrednich dowodów na to brak.

98 Być może dla komunikacji z nowym budynkiem wykonano już wtedy przejście od izby mieszkalnej w ścianie zachodniej. Opis w aktach katastralnych przedstawia jeszcze budynek szkieletowy, zaś dołączony załącznik z rysunkiem pokazuje już stan po przebudowie w latach 90. XIX w. Zob. APT, UKT, sygn. 175, nr 7 oraz załącznik nr 2 do wykazu zmian. 
wany równolegle do karczmy, wzdłuż drogi. Prostopadle do niego znajdowała się stodoła, zamykając podwórze od strony wschodniej. Równolegle do niej usytuowana była szkieletowa nieogrzewana kręgielnia do gry w kręgle. $\mathrm{Na}$ środku podwórza usytuowana była również wolnostojąca kuchnia (il. 8).

Podczas remontu w latach 1897-1898 przede wszystkim zastapiono szkieletowy budynek sali tanecznej nowym, murowanym z cegły (il. 9). Wejście do niego prowadziło od podwórza, bezpośrednio do izby gościnnej oraz dużej sali tanecznej. Z obu pomieszczeń prowadziło wejście do garderoby $^{99}$. Izba była również skomunikowana z izbą mieszkalną karczmarza w budynku drewnianym. W obrębie tej części wprowadzono murowaną ściankę działową części zachodniej, zaś do izb piece grzewcze ${ }^{100}$. Wprowadzenie kanałów dymnych wymusiło zamurowanie trzonów i wprowadzenie pieca kuchennego w czarnej kuchni. W tym okresie zamurowano wejście do sieni północnej, wprowadzając w to miejsce okno. W obrębie podwórza w dalszym ciagu funkcjonowała stajnia, stodoła, kuchnia i kręgielnia.

W 1926 r. doszło do kolejnej zmiany w przestrzeni budynku. Do ściany północnej izby gościnnej domu drewnianego dostawiono przybudów$\mathrm{kę}^{101}$. W takim stanie karczma funkcjonowała do lat 40. XX w., pozostając przez cały czas w rękach rodziny Ross.

Poniższe informacje poparte ogólną wiedzą na temat rozwoju miejsc rozrywki pozwalają na wysnucie kilku wniosków. Po pierwsze budynek powstały najprawdopodobniej na początku XIX w. od samego początku przeznaczony był na karczmę ${ }^{102}$. Choć brak informacji historycznych na jego

99 W planie archiwalnym określono je jako inne pomiesz̨zenie, natomiast opis z $1926 \mathrm{r}$. jednoznacznie mówi o pokoju do garderoby. Zob. ibidem, załącznik nr 1 do wykazu zmian.

100 Najstarsze opisy mówią o izbach ogrzewanych, choć najprawdopodobniej łączyło się to z sąsiedztwem trzonów czarnej kuchni. Natomiast opis z 1926 r. bezpośrednio mówi o izbach ogrzewanych piecami. Do zmiany tej musiało zatem dojść na przełomie XIX i XX w. Zob. ibidem.

101 Ibidem. Obecnie po zmianie tej nie ma już śladu, dlatego nie wyodrębniono jej w graficznym rozwarstwieniu.

102 Świadczy o tym nie tyle sam układ przestrzenny, nie odbiegający od typowych rozwiązań mieszkalnych, co konstrukcja samego komina butelkowego o znacznie większych rozmiarach, już od początku przygotowanego do obsługi dwóch niezależnych trzonów kuchennych - gościnnego i domowego. 
temat w pierwszym okresie działania, mógł on być już prywatną własnością chłopa utrzymującego się z prowadzenia karczmy. Jego wielkość, konstrukcja oraz forma świadczą jednak o lokalnym zbycie, nie nastawionym na szerszą grupę użytkowników. Główną częścią była duża izba karczemna usytuowana w północno-wschodniej części. Z czasem została ona przebudowana, aby uzyskać dodatkowe, wydzielone pomieszczenia dla gości. W układzie tym nie zmieniały się tylko pomieszczenia mieszkalne karczmarza. Zapewne w drugiej połowie XIX w. do istniejącego budynku dostawiono dodatkową szkieletową część po stronie zachodniej, w której mieściła się sala taneczna. W obrębie zagrody, poza budynkami gospodarczymi, pojawiła się także kręglarnia. Jak wyglądały tego rodzaju budynki, możemy zobaczyć dzięki podręcznikom budowlanym z końca XIX wieku ${ }^{103}$ (il. 10). $\mathrm{Na}$ widokówce z początku XX w. widzimy „Karczmę Rossa” po stronie południowej z założeniem ogrodowym i rozstawionymi ławkami (il. 11). W okresie tym część szkieletową zamieniono na murowaną z cegły, z salą taneczna, izbą gościnną oraz garderobą.

Elementy te świadczą niewątpliwie o zmianie potrzeby spędzania wolnego czasu, niezwiązanego już jedynie z konsumpcją i alkoholem, ale i szerszym spektrum rozrywki. Było to niewatpliwie próbą dorównania przez już uwłaszczonych, nierzadko o znacznym statucie majątkowym chłopów, upodobaniom i ówczesnej modzie mieszczan. Mowa tu oczywiście o ogrodzie ludowym, w tym miejscu jednak o mocno zredukowanym układzie. Bez muszli koncertowych, promenad i letnich teatrów o ograniczonej formie fragmentu zieleni z ustawionymi stolikami i miejscem do gry w kręgle, które były, co warto podkreślić, dość popularną formą spędzania czasu również na wsi ${ }^{104}$.

W niektórych miejscowościach, zwłaszcza podmiejskich, rozwój miejsc rozrywki był jeszcze bardziej intensywny. Dobrym tego przykładem jest

\footnotetext{
103 Sam tor miał długość ok. $20 \mathrm{~m}$, połączony był z wydzielonym miejscem, w którym usytuowane były stoliki. Całość wykonana w konstrukcji szkieletowej, z licznymi ażurowymi dekoracjami wpisywała się formą w nurt architektury uzdrowiskowej. Zob. Die Bau und Kunstzimmerei mit besonderer berücksichtigung der ausseren Form, hrsg. T. Krauth, F. S. Meyer, B. 2, Leipzig 1893, Tafel 117, 118.

104 Znane były one i w innych wsiach nadwiślańskich. Zob. APT, UKT, sygn. 1035, s. 5, sygn. 1004, s. 12, sygn. 1050, s. 21.
} 
choćby Czerwona Karczma we wsi Dragacz ${ }^{105}$. Znajdowała się w tym miejscu, co najmniej już w XVIII wieku ${ }^{106}$. Dobre usytuowanie przy przeprawie do prężnie rozwijającego się w tym czasie Grudziądza doprowadziło do przebudowy tego budynku na nowoczesny murowany, mieszczacy restauracje, pokoje gościnne i założenie ogrodowe na zapleczu. Podobnie rzecz miała miejsce w niedalekim Michalu, gdzie w na przełomie XIX i XX w. zbudowany został Etablissement Pennera (il. 12) ${ }^{107}$. Było to założenie w skład, którego wchodziła restauracja, kawiarnia, sala taneczna, dodatkowe pokoje dla gości, w ogrodzie zaś muszla koncertowa, letni bufet i kręgielnia, mogące pomieścić razem 300 osób ${ }^{108}$. Wystrój wnętrz oraz układ funkcjonalny przewyższał niejedne takie założenie miejskie.

Oczywiście zabudowań takich na wsi pomorskiej było znacznie więcej. Jak widzimy różniły się one w zależności od czasu powstania i przeznaczenia. Zaprezentowane w niniejszym tekście przykłady są oczywiście jednymi z wielu, nie ukazując całego spektrum zagadnienia. W przyszłości należałoby opracować dokładny katalog tych zabytków architektury, dziś zupełnie pomijanych w inwentarzach jak i badaniach terenowych wsi, zaś dla najciekawszych karczem wykonać pełne badania historyczno-architektoniczne dajace rzeczywisty obraz pierwotnego układu i zmian, jakim podlegały.

Powróćmy jeszcze do karczmy w Górsku. Przeprowadzone badania historyczno-architektoniczne dowiodły, że był to bardzo ciekawy przykład budynku, obrazującego rozwój od skromnej, drewnianej, tradycyjnej gospody z początku XIX w. do układu, choć w zredukowanej formie, nawiązujacego do modnych pod koniec wieku ogrodów ludowych. Odzwierciedlała ona poprzez to, choć w bardzo lokalnym wymiarze, zmianę w sposobie spędzania wolnego czasu przez uwłaszczonych gospodarzy, bezpośrednio nawiązując do rozwiązań miejskich. Niestety budynek ten został rozebra-

\footnotetext{
105 http://www.dragacz.pl/index.php?option $=$ com_content\&view $=$ article\&id $=108 \% 3$ Asz lakiem-osadnikow-holenderskich-i\&catid=35\&Itemid=58, 22.12.2011.

106 Zbudowana była w konstrukcji szkieletowej, posiadając również stan. Zob. Lustracja wojewódz̨tw Prus Królewskich 1765, t. 2, s. 85.

107 Michale, tzw. Biała Karczma, KEZAIB, oprac. Z. Werterowska, Bydgoszcz 1994, mps w zbiorach WUOZB; Grudziadz i okolice na starej karcie pocztowej, t. 2, Grudziądz 2006, s. 108 .

108 Michale, KEZAIB, załącznik nr 1.
} 
ny. Nie znajdował się również w ewidencji ani katalogu zabytków. Dobitnie obrazuje to, jak niewiele jeszcze wiemy o tego typu założeniach, nie dostrzegając w nich wartości zabytkowych, poprzez które podlegać moga one ochronie, choćby w podstawowym wymiarze ${ }^{109}$.

\section{Summary}

\section{Development of rural entertainment places in the $19^{\text {th }}$ and the beginning of the $20^{\text {th }}$ century. A study based on the example of the results of historical and architectural research of „Tavern Ross” in Górsk}

For many centuries inns have been important elements of rural landscape. Their layout and form were dependant on the present state of the country. Generally, inns can be divided into so called depot inns, where travelers could stay, and inns (taverns) for the local people. In the $19^{\text {th }}$ century, when peasants were finally emancipated, shape of the inns started to develop.

The aim of this paper is to describe the results of historical and architectural research of wooden inn situated in a village of Górsk, about $15 \mathrm{~km}$ from Torun. The abovementioned research enabled to reconstruct the original layout of the building as well as all the changes in its construction that were being made in the $19^{\text {th }}$ and at the beginning of the $20^{\text {th }}$ century.

The inn in Górsk was a typical one, devoted to the villagers. With time, its spatial and functional layout started to evolve due to the needs of the local community. At the end of the $19^{\text {th }}$ century the inn was extended by a large dancing hall which was layed with stone. In the backyard there was a small garden with a number of benches and a bowling alley. All those changes related to fashionable gardens in the cities.

\footnotetext{
109 W starszych wydaniach katalogów karczmy wymieniano sporadycznie. Te nowsze również traktują to zagadnienie niekonsekwentnie. Karczma w Michalu znalazła się spisie, natomiast analogiczne założenie we wsi Dragacz już nie. Por. Katalog Zabytków Sztuki w Polsce, t. XI, Dawne województwo bydgoskie, red. T. Chrzanowski, M. Kornecki, Z. 4, Dawny powiat chełmiński, oprac. T. Mroczko, Warszawa 1976, s. 91; Zabytki architektury i budownictwa w Polsce. Wojewódz̧two bydgoskie, Warszawa 1997, cz. 2, s. 82, 84. Taki stan jest odzwierciedleniem samego rejestru zabytków. Zob. http://www.nid.pl/UserFiles/File/Rejestr \%20Zabytk $\%$ C3\%B3w/rejestr $\% 20$ zabytk $\%$ C3\%B3w $\% 20$ nieruchomych $\% 20 \% 20$ stan\%20na\%2030_09_2011/KUJ-rej.pdf, 21.12.2011, s. 73-74.
} 
Unfortunately, the inn in Górsk, which was the last example of the building of this type in Chełmno region, was dismantled in 2009. It makes us aware of the fact that we still know very little about this kind of buildings and that they do not subject to any preservation maintenance. 


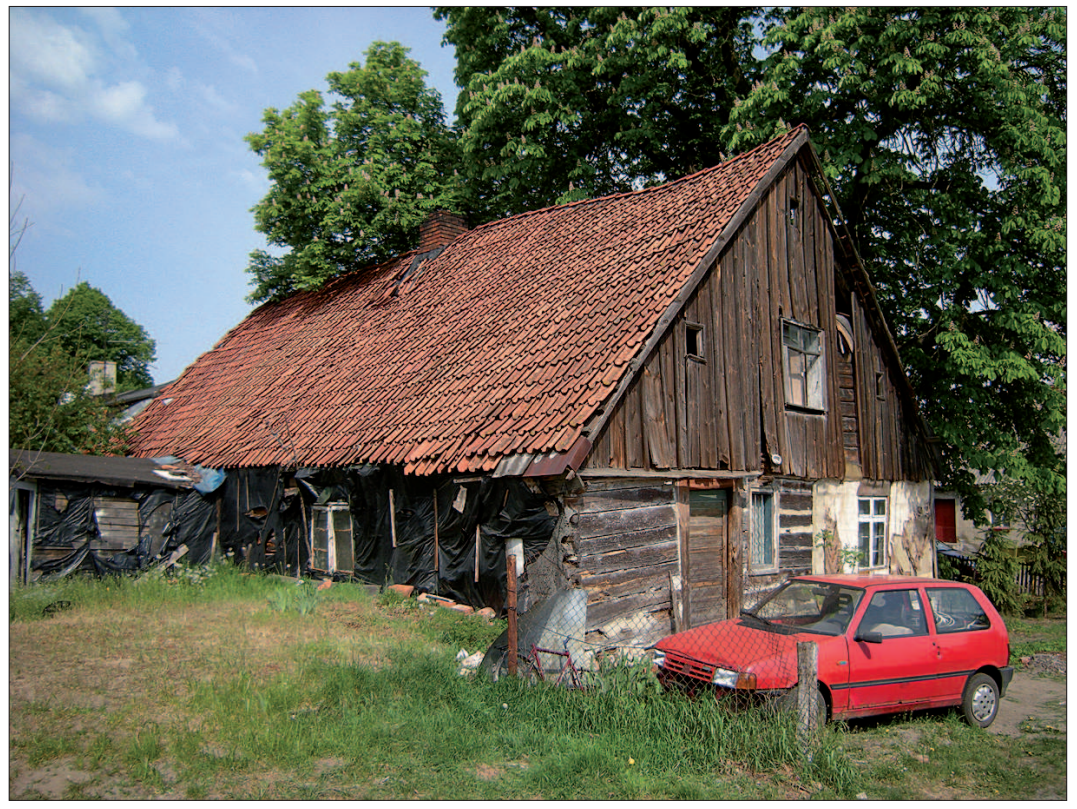

Il. 1. Górsk, „Karczma Rossa” z początku XIX w. Obecnie nieistniejacca. Widok od strony południowo-zachodniej (fot. M. Prarat, 2011)

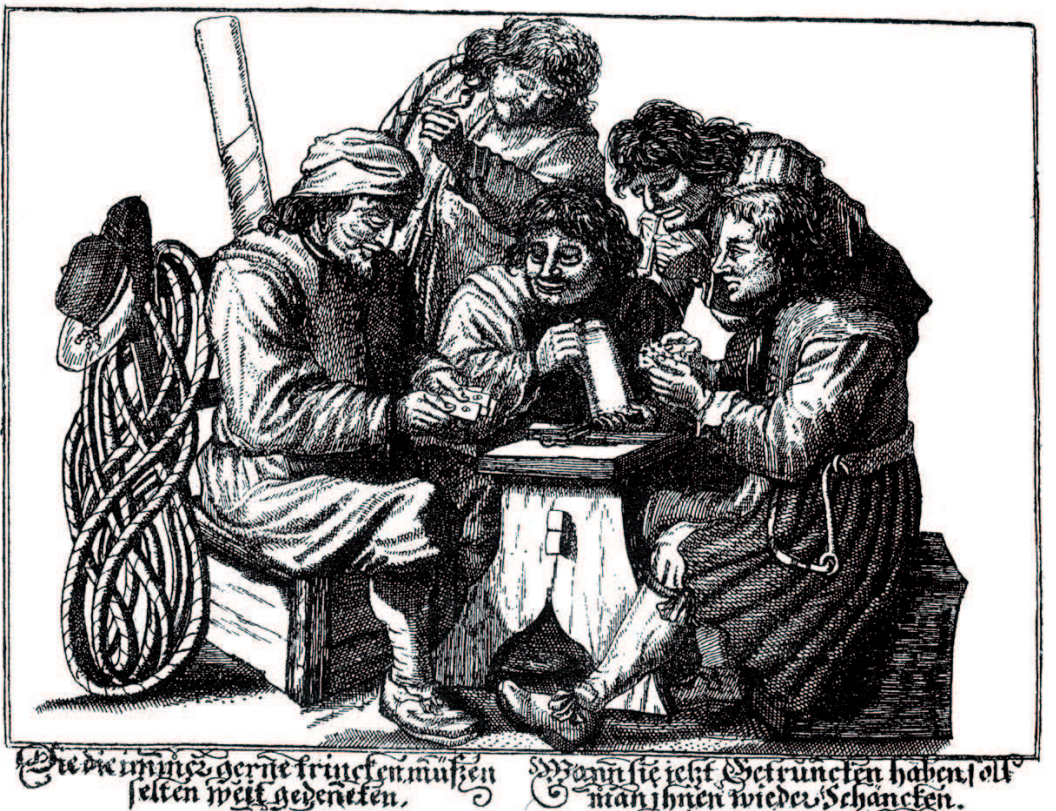

Il. 2. Scena w karczmie podczas gry w karty, ok. 1700 r. (E. Mummenhoff, Der Handwerker in der deutschen Vergangenheit, Jena 1924, Abb.100 - reprint) 


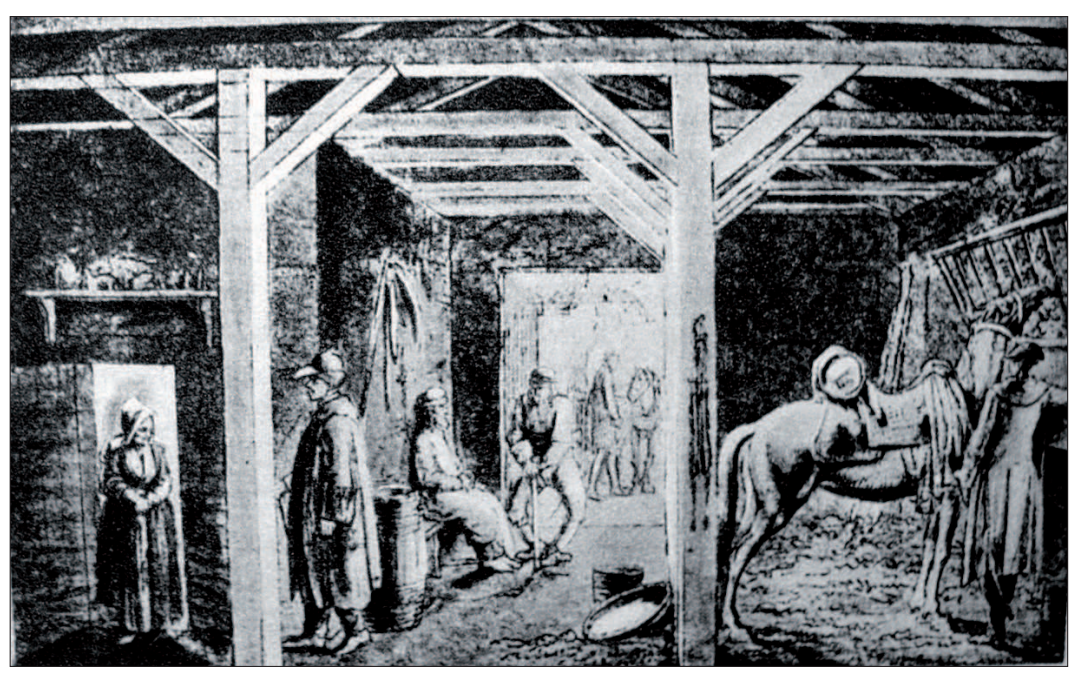

Il. 3. Widok stanu w zajeździe na Pomorzu wg. rysunku D. Chodowieckiego (reprodukcja za: T. Chrzanowski, Karczmy i zajazdy polskie, Warszawa 1958, s. 7, il. 4)

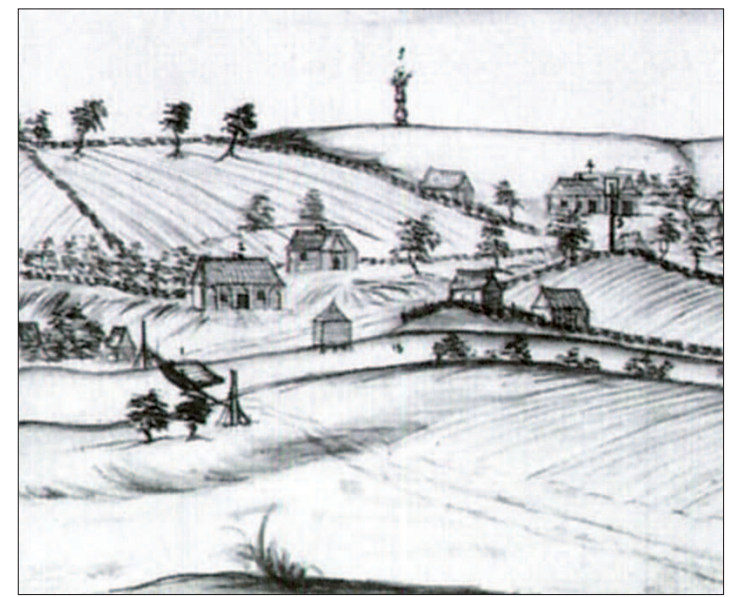

Il. 4. Widok na wieś Lubicz 1 połowy XVIII w. Na pierwszym planie karczma wiejska, w tle karczma zajezdna (Torun $i$ miasta ziemi chetminskiej na rysunkach Jerzego Fryderyka Steinera z piernszej potony XVIII wieku, tow. Album Steinera, Torun 1998, s. 149) 


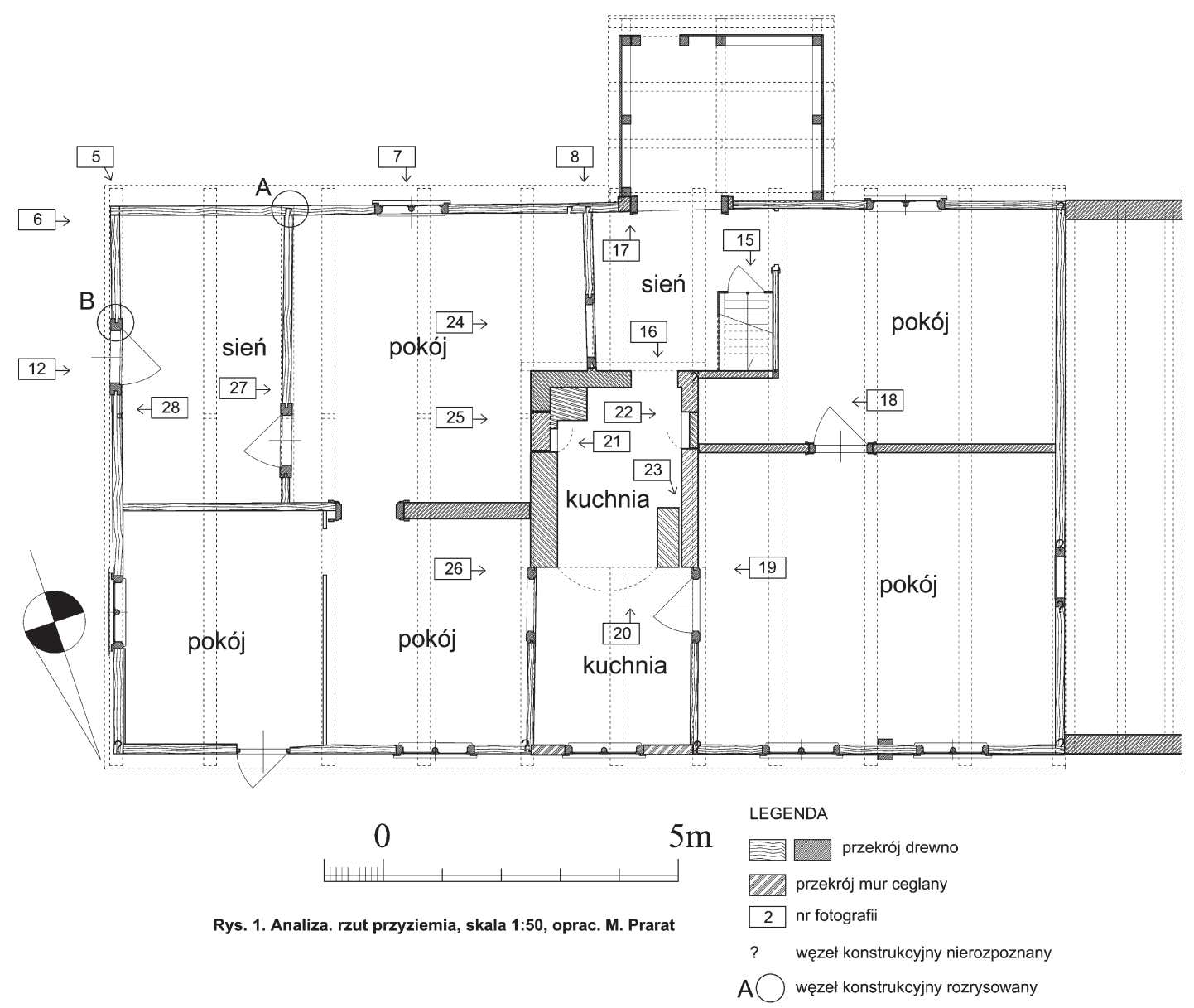

Il. 5. Górsk, „Karczma Rossa” z początku XIX w. Badania architektoniczne. Analiza, rzut przyziemia (oprac. M. Prarat)

Il. 6. Górsk, „Karczma Rossa” z początku XIX w. Widok na ścianę zachodnią. Oznaczenia: A - ślad po pierwotnej ściance działowej połączonej z główną na czop płetwowy, B - ślad po pierwotnej ściance działowej w podwalinie, za którą zaczyna się fazowanie (fot. M. Prarat, 2011)

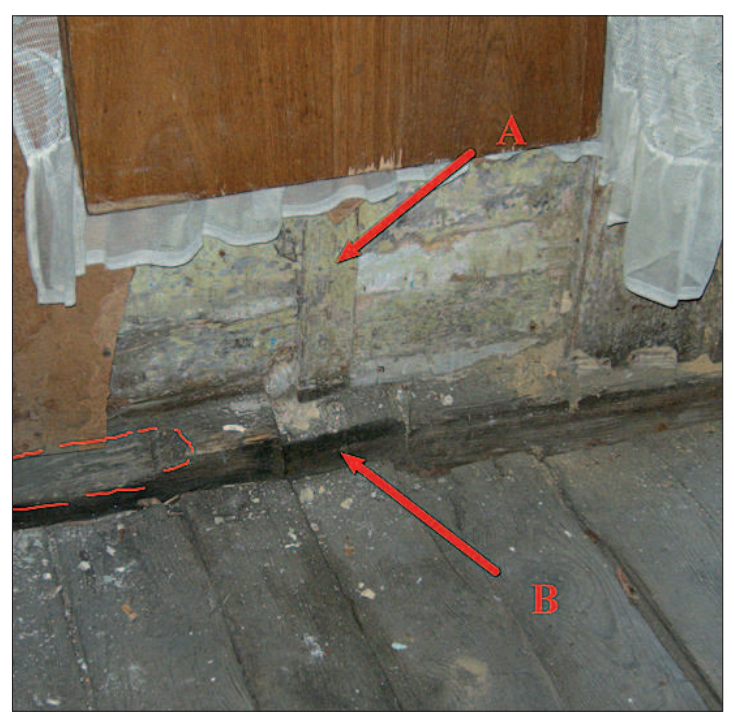


[446]
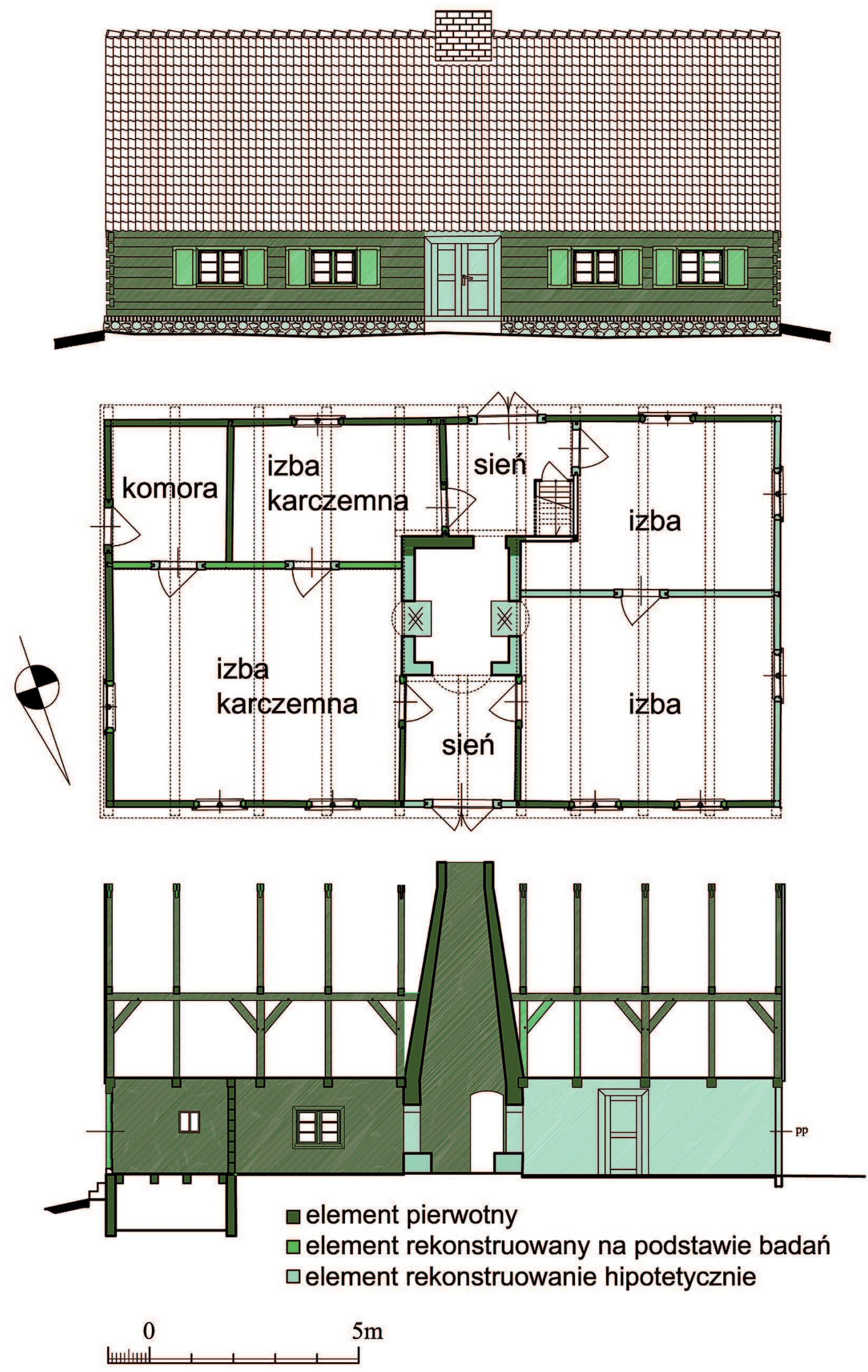

Il. 7. Górsk, „Karczma Rossa” z początku XIX w. Hipotetyczna rekonstrukcja stanu pierwotnego, rzut przyziemia, przekrój poprzeczny, elewacja północna (oprac. M. Prarat) 


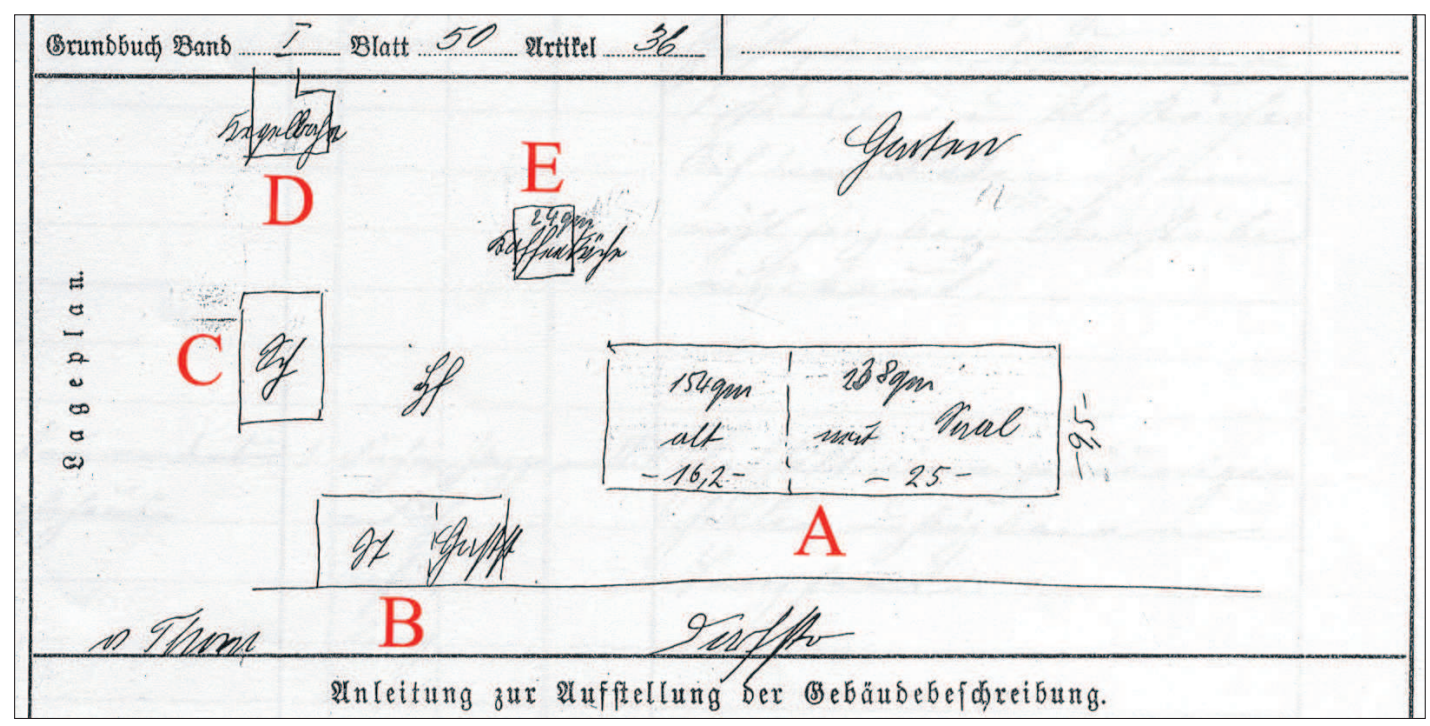

Il. 8. Górsk, „Karczma Rossa” z początku XIX w. Plan sytuacyjny z przełomu XIXXX w. Oznaczenia: A - karczma wraz z nowa przybudówka, B - budynek inwentarski, C - stodoła, D - kregielnia, E - wolnostojąca kuchnia (Archiwum Państwowe w Toruniu, Urząd Katastralny w Toruniu, sygn. 175, nr 7).
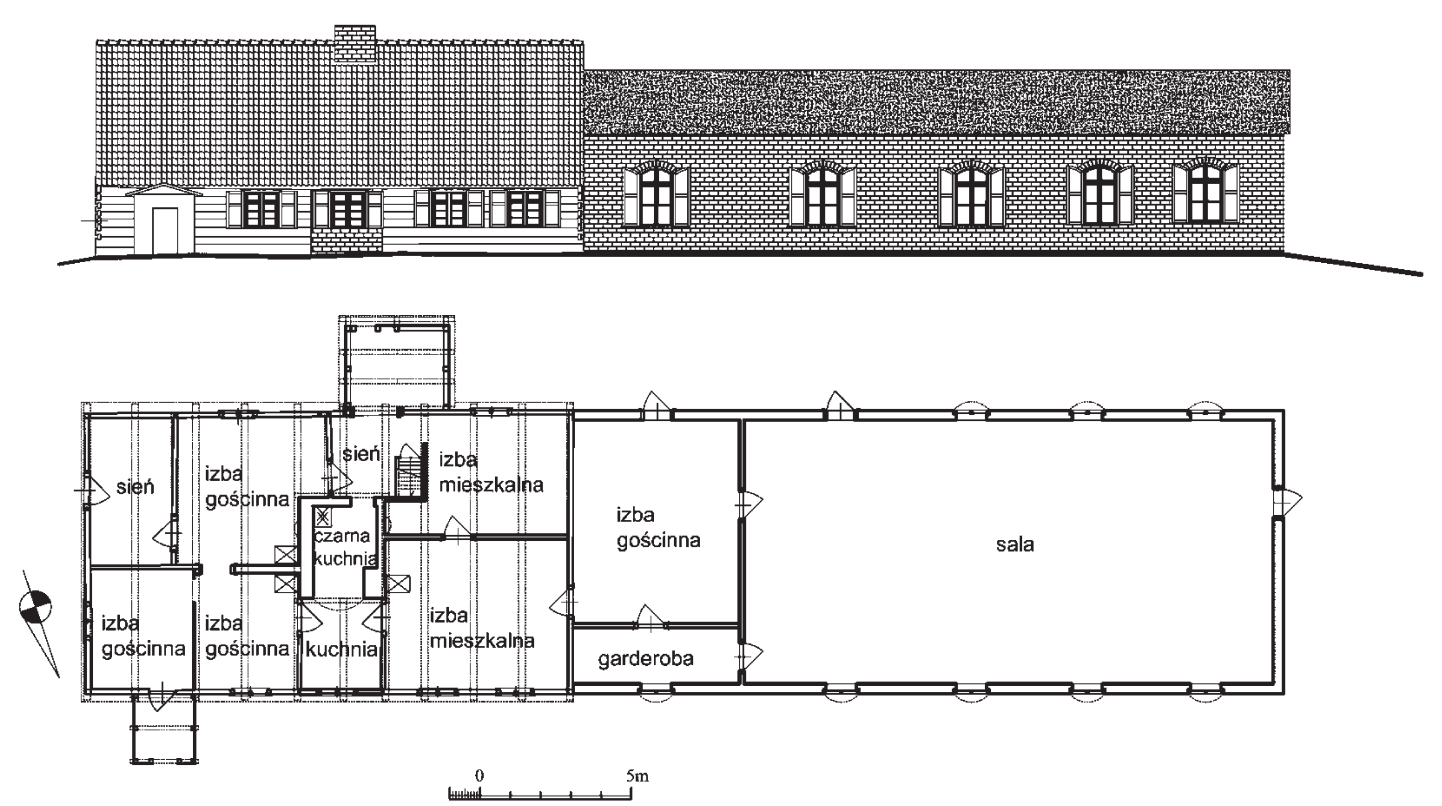

Il. 9. Górsk, „Karczma Rossa” z początku XIX w. Rzut przyziemia, elewacja północna, rekonstrukcja $\mathrm{z}$ lat 20. XX w. (oprac. M. Prarat) 


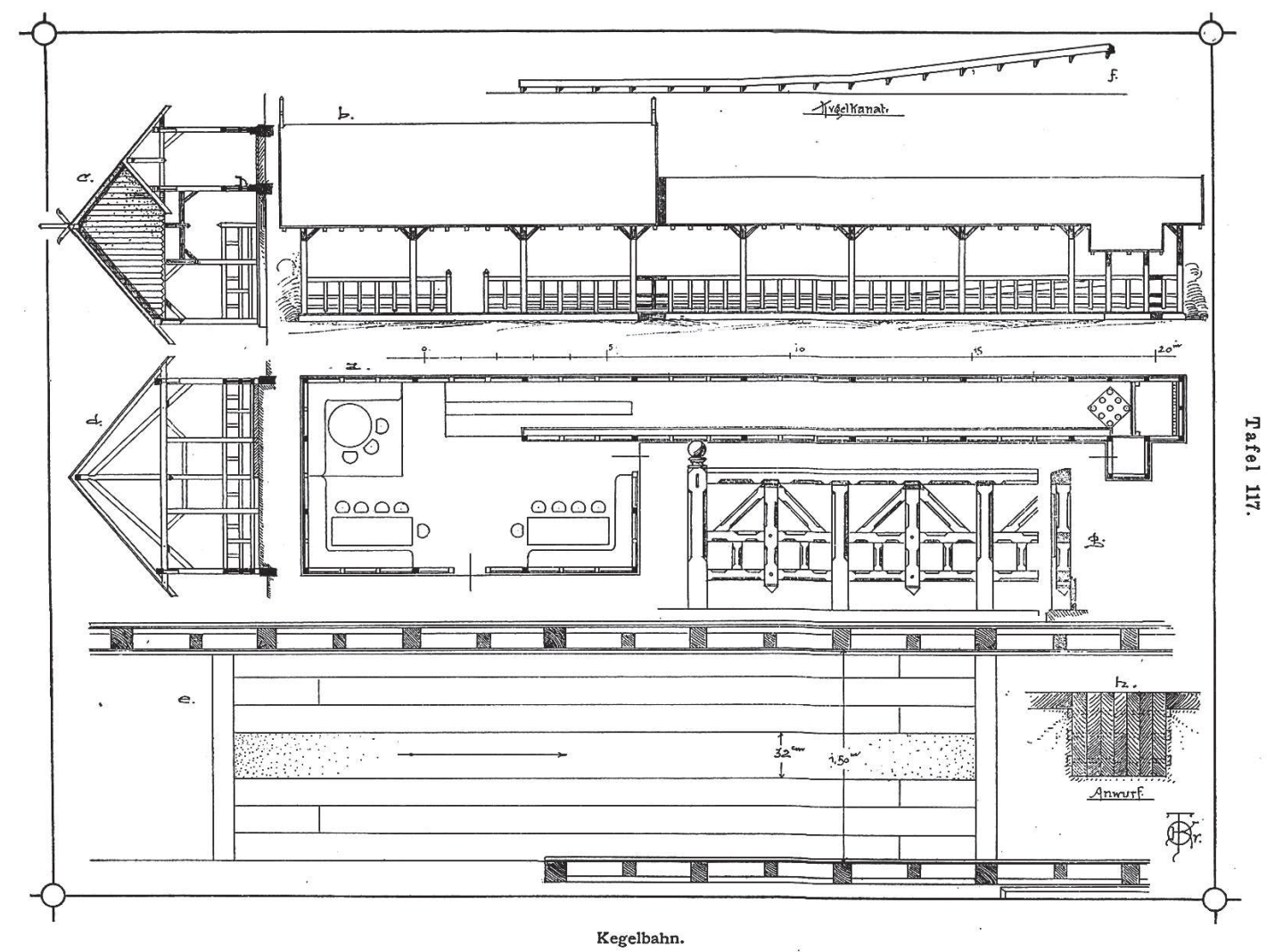

Il. 10. Projekt wolnostojącej kręgielni wraz z wyposażeniem. (Die Bau und Kunstzimmerei mit besonderer berïcksicbtigung der ausseren Form, hrsg. T. Krauth, F. S. Meyer, B. 2, Leipzig 1893, Tafel 117) 


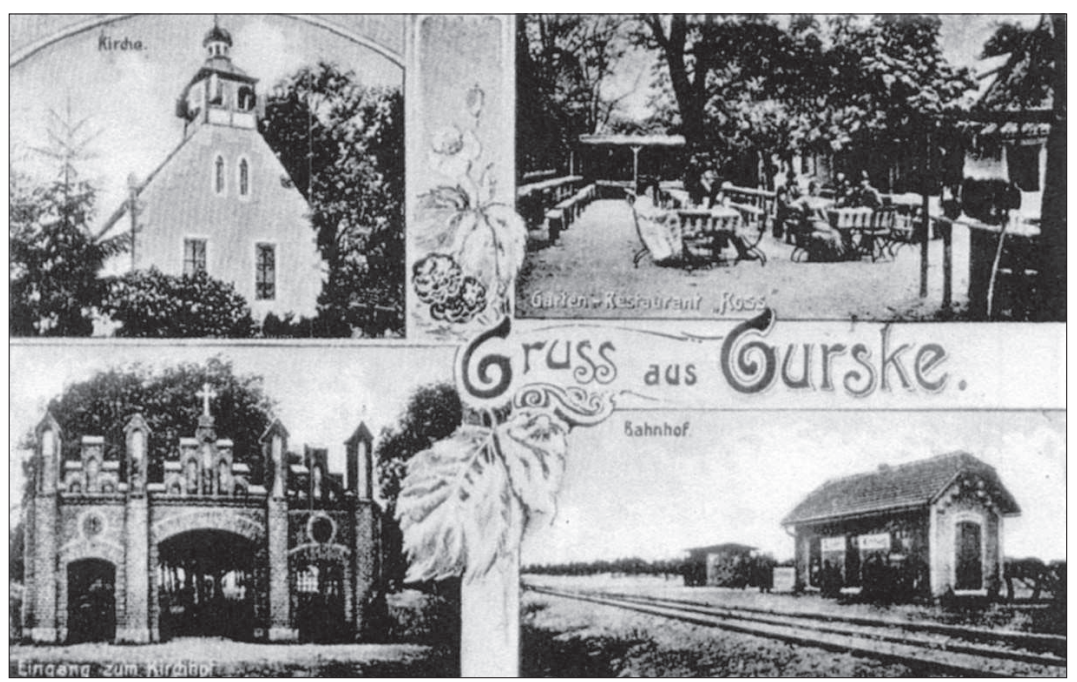

Il. 11. Górsk, pocztówka z początku XX w. Widoczne założenie Karczmy Rossa od strony południowej z ogródkiem i ławkami. (A. Walczyński, Górsk i okolice od prehistorii do potony XX wieku, Toruń 2005 , s. 30)

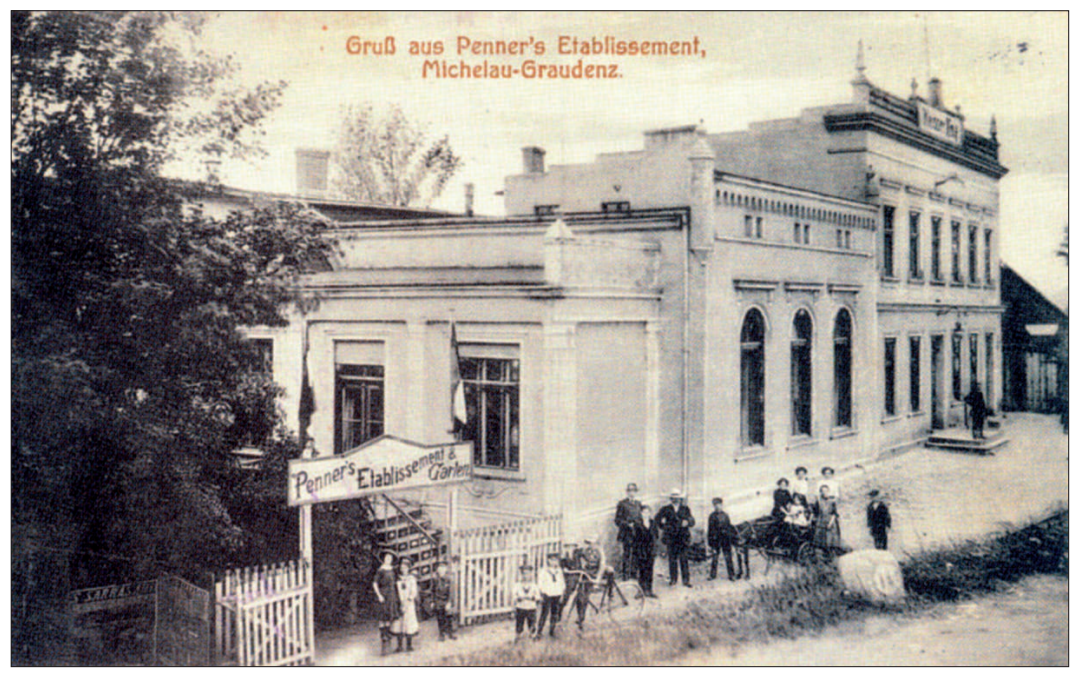

Il. 12. Etablissement Pennera w wsi Michale, zbudowany na przełomie XIX i XX w. (Grudziadz, i okolice na starej karcie pocatowej, t. 2, Grudziądz 2006, s. 108) 